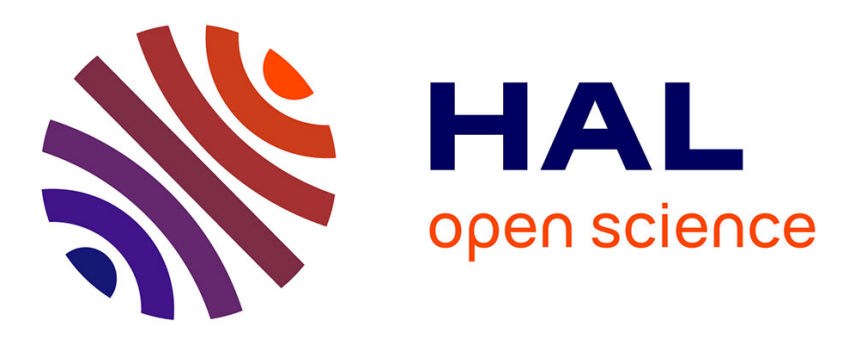

\title{
Habitat partitioning among three predatory fish in a temperate reservoir
}

\author{
Samuel Westrelin, Julien Cucherousset, Romain Roy, Laurence Tissot, \\ Frédéric Santoul, Christine Argillier
}

\section{- To cite this version:}

Samuel Westrelin, Julien Cucherousset, Romain Roy, Laurence Tissot, Frédéric Santoul, et al.. Habitat partitioning among three predatory fish in a temperate reservoir. Ecology of Freshwater Fish, 2021, 10.1111/eff.12619 . hal-03268555

\section{HAL Id: hal-03268555 \\ https://hal.inrae.fr/hal-03268555}

Submitted on 23 Jun 2021

HAL is a multi-disciplinary open access archive for the deposit and dissemination of scientific research documents, whether they are published or not. The documents may come from teaching and research institutions in France or abroad, or from public or private research centers.
L'archive ouverte pluridisciplinaire HAL, est destinée au dépôt et à la diffusion de documents scientifiques de niveau recherche, publiés ou non, émanant des établissements d'enseignement et de recherche français ou étrangers, des laboratoires publics ou privés. 


\section{Habitat partitioning among three predatory fish in a temperate reservoir}

\section{How to cite this article:}

Westrelin, S., Cucherousset, J., Roy, R., Tissot, L., Santoul, F., \& Argillier, C. (2021). Habitat partitioning among three predatory fish in a temperate reservoir. Ecology of Freshwater Fish, 00, 1-14. https://doi. org/10.1111/eff.12619

\section{Authors}

Samuel Westrelin ${ }^{(1)}$, Julien Cucherousset ${ }^{(2)}$, Romain Roy $^{(3)}$, Laurence Tissot ${ }^{(3)}$, Frédéric Santoul ${ }^{(4)}$, Christine Argillier $^{(1)}$

(1) INRAE, Aix Marseille Univ, Pôle R\&D ECLA, HYNES, RECOVER, 3275 Route de Cézanne - CS 40061, F-13182 Aix-en-Provence Cedex 5, FRANCE

(2) CNRS, Université Paul Sabatier, ENFA, UMR5174 EDB, 118 route de Narbonne, 31062 Toulouse, FRANCE

(3) EDF R\&D LNHE - Laboratoire National d'Hydraulique et Environnement, HYNES (INRAE-EDF R\&D), 6 Quai Watier, CHATOU Cedex 78401, France

(4) Laboratoire écologie fonctionnelle et environnement, Université de Toulouse, CNRS, Toulouse, FRANCE

\section{Contact}

Samuel Westrelin

INRAE

3275 Route de Cézanne - CS 40061

F-13182 Aix-en-Provence Cedex 5

France

samuel.westrelin@inrae.fr

+33(0)4 42666971

\section{Abstract}

The diversity of predatory species plays a key role in ecosystem functioning but our understanding of the mechanisms underlying their coexistence is limited, particularly in freshwater ecosystems. Northern pike Esox lucius, European perch Perca fluviatilis and pikeperch Sander lucioperca are three widespread predatory species 
in European lakes, where they often coexist. As potential competitors, we hypothesized that partitioning habitat is a determinant of species coexistence. This was tested by quantifying the variability of their habitat use in tracking adult individuals in the Bariousses reservoir (France, 86.6 ha, mean depth $7.1 \mathrm{~m}$ ). Specifically, we investigated their distribution along the littoral - pelagic and depth axes along the daily cycle and across seasons. From littoral to pelagic waters were first found pike, then perch and finally pikeperch. Pike was the closest to the surface while pikeperch was the deepest. This general pattern was, however, variable across seasons with the three species located in the upper layer in summer during reservoir stratification. Individuals were more evenly distributed along the littoral-pelagic axis and closer to the bottom when water was mixing (autumn, winter). In summer, perch used more intensively the pelagic zone during daytime. Other species did not show any diel change of habitats. Our results highlighted that species coexistence is associated with habitat partitioning among these three predators, with perch showing a more variable behavior regarding habitat characteristics. Now more than ever, in the context of global change which modifies habitats, it is of crucial importance to understand coexistence mechanisms of species that shape ecosystems.

Keywords: Esox lucius; Perca fluviatilis; Sander lucioperca; littoral - pelagic habitat use; vertical habitat use; diel and seasonal habitat use 


\section{Introduction}

Top predators play a key role in ecosystem functioning (Hairston et al., 1960; Fretwell, 1987) and more specifically their diversity is of the utmost importance (Sinclair et al., 2003). Understanding how these competing species can coexist (Sommer, 1999) is a crucial question in ecology (Schmitz, 2007). The differential use of resources among species (i.e. resource partitioning) is a key mechanism allowing species coexistence (Schoener, 1986; Chesson, 2000). In fish, niche segregation was shown to be primarily driven by partitioning of food resources and habitat (Ross, 1986). The coexistence of fish can also occur through more complex mechanisms such as spatial segregation with diet overlap linked to different feeding strategies or foraging sites (e.g. Sala \& Ballesteros, 1997; Liedke et al., 2017; Pothoven, 2018; Raby et al., 2019). Competition can lead to shift of habitat use and diet (e.g. Brodersen et al., 2012). To date, however, our understanding of the coexistence of top predators in lakes is overall limited (but see Guzzo et al., 2016).

Northern pike (Esox lucius, hereafter pike), European perch (Perca fluviatilis, hereafter perch) and pikeperch (Sander lucioperca) are three common predatory species in European lakes (Kottelat \& Freyhof, 2007) that are primarily piscivorous when adults, although variability in their diet has commonly been reported (Campbell, 1992; Craig, 2008). Pike is a diurnal predator that ambushes prey (Raat, 1988; Eklöv, 1997); perch can hunt in schools during daytime in pelagic zone (Eklov, 1992; Craig, 2000) and pikeperch hunts in the twilight in open waters (Craig, 2000). These different feeding strategies could favor a trophic segregation, with competition affecting the trophic niche of perch (Schulze et al., 2012). In ectotherms, environment may influence resource partitioning to fulfill physiological requirements as optimal temperature and oxygen conditions vary among species, especially in the case of stratified lakes where vertical gradients of temperature and oxygen segregate the physical habitat, depending on the season. This affects the spatial distribution of fish (Magnuson et al., 1979) and habitat partitioning could then be more pronounced in stratified lakes (Guzzo et al., 2016). These three species have different physiological requirements for temperature and oxygen that could contribute to their coexistence (Helland et al., 2008; Verberk et al., 2012) along environmental gradients. The optimum temperatures increase from pike to perch and pikeperch, $10-24^{\circ} \mathrm{C}, 16-27^{\circ} \mathrm{C}$ and $27-30^{\circ} \mathrm{C}$, respectively (Souchon $\&$ Tissot, 2012). Perch is able to cope with hypoxic conditions down to 1.1-2 mg/L (Jones, 1964) while pike avoids zones with less than 3-4 mg/L of dissolved oxygen (Casselman \& Lewis, 1996) and pikeperch appears as the most demanding in oxygen $\left(>4 \mathrm{mg} / \mathrm{L}\right.$ at $5^{\circ} \mathrm{C}$ and $>7 \mathrm{mg} / \mathrm{L}$ at $20^{\circ} \mathrm{C}$, Dolinin, 1974). Pike is mainly littoral and present in shallow waters (Chapman \& Mackay, 1984a; Craig, 1996). In summer, piscivorous perch frequents the pelagic zone during daytime and moves to the littoral, laying on the bottom, during the night (Imbrock et al., 1996; Pekcan-Hekim et al., 2005), while it migrates to deeper waters in winter (Thorpe, 1977). Pikeperch prefers open waters and occupies deeper waters in winter compared to summer (Vehanen \& Lahti, 2003). In a manipulative experiment, Schulze et al. (2006) showed that the introduction of pikeperch in a lake where pike and perch were residential led to a shift of perch habitat use towards the littoral over spring and summer. While these studies suggest that habitat segregation might occur among the three species when they coexist, quantification of their habitat use, including the vertical dimension and daily cycle, is lacking.

In the present study, we quantified the habitat use of coexisting pike, perch and pikeperch in a deep reservoir in France. Adults of each species were tracked over two years and their spatial distribution (littoral pelagic and vertical) analyzed over the different stratification periods and over the daily cycle. We predicted that species coexistence was associated with habitat partitioning, pike mainly using the littoral zone, pikeperch 
deeper waters and perch the pelagic zone. We expected these main patterns to vary across seasons, when the lake was stratified and the physical habitat became very constraining. We also expected some diel variation associated with the circadian rhythm of each species.

\section{Materials and methods}

\subsection{Study site}

The study was conducted in the Bariousses reservoir $\left(45.33^{\circ} \mathrm{N}, 1.49^{\circ} \mathrm{E}\right)$ in the western central part of France (Figure 1). At the mean water level, which was hourly measured by Electricité de France (EDF), its area covered 86.6 ha, mean depth was $7.1 \mathrm{~m}$ and maximum depth was $19.4 \mathrm{~m}$. Main annual features emerge in the water regulation scheme of this reservoir whose levels varied between $507.1 \mathrm{~m}$ and $513.5 \mathrm{~m}$ above sea level over the study period (March 2012 - March 2014). High water levels (> 511.9 m, quantile 66\%) are from far the most frequent in spring whereas the low ones $(<511.3 \mathrm{~m}$, quantile $33 \%)$ are the most frequent in autumn because, at the beginning of this season, the water level is lowered in order to collect rainwater. In winter, water levels are more evenly distributed over their whole range. In summer, the water level is kept stable around its mean value ([511.3; $511.9 \mathrm{~m}]$ ) to sustain recreational activities concentrated between the shore and the island (Figure 1). The thermal regime of this reservoir was monomictic with four distinct temperature regimes. In spring (April to June), the water temperature rapidly increased and stratification occurred. In summer (July to September), water was warmer and a thermocline at about $4.5 \mathrm{~m}$ depth was observed. In autumn (October to December), water temperatures decreased rapidly when water mixing occurred and, in winter (January to March), water was mixed and homogeneously cold (Figure 2). The summer thermocline was associated with an oxycline that separated saturated surface waters from unsaturated deep waters; the hypolimnion had an oxygen saturation rate ranging from approximatively $40 \%$ (4 $\mathrm{mg} / \mathrm{L})$ at its top to $15 \%(1.5 \mathrm{mg} / \mathrm{L})$ at its basis. During the other seasons and over all depths, the dissolved oxygen concentration was $6 \mathrm{mg} / \mathrm{L}$ at the lowest. Representative oxygen profiles based on measurements made in 2011 are given in Online Resource 1. The Secchi transparency depth varied between 1.3 and $2.5 \mathrm{~m}$. In 2010, measurements made for the European Water Framework Directive monitoring program (EC, 2000) gave concentrations of 0.73 $\mathrm{mg} / \mathrm{L}$ and $<0.01 \mathrm{mg} / \mathrm{L}$ for total nitrogen and total phosphorus in the euphotic zone, respectively. This corresponds to an oligotrophic reservoir. The fish assemblage of the reservoir was determined with a standardized procedure using a multi-mesh gillnet fishing protocol in 2010 (CEN, 2005) and included 11 species. It was dominated by Cyprinidae and Percidae, as commonly observed in lowland reservoirs (Irz et al., 2002). In terms of catch per unit effort (cpue, number per net in 12 hours), the dominant species were roach (Rutilus rutilus, cpue 0.37, biomass per unit effort -bpue in g per net in 12 hours, 15.3), ruffe (Gymnocephalus cernua, cpue 0.14, bpue 2.1), perch (cpue 0.06, bpue 3.6), pikeperch (cpue 0.02, bpue 4.0) and common bream (Abramis brama, cpue 0.01, bpue 3.7). In terms of bpue, the dominant species were roach, carp (Cyprinus carpio, bpue 10.7, cpue <0.01), tench (Tinca tinca, bpue 8.3, cpue <0.01), chub (Squalius cephalus, bpue 4.8, cpue <0.01), pikeperch and common bream. 


\subsection{Fish tagging}

The surgical procedure is detailed in Westrelin et al. (2018) as advocated by Thiem et al. (2011). Specifically, a total of 17 pike, 29 perch and 25 pikeperch, all adults, were caught by fishing in the whole reservoir or with nets set up at dawn, during daytime and at dusk for a maximum of 2 hours over four sampling campaigns (winter, summer and autumn 2012 and spring 2013). Fyke nets were used in shallow areas ( $<3 \mathrm{~m} \mathrm{depth}$ ), whereas in deeper areas, pelagic gillnets fishing from $2 \mathrm{~m}$ above the bottom and benthic gillnets fishing up to $2 \mathrm{~m}$ above the bottom were set. Twelve pikeperch originating from a fish farm completed this sample. Fish mean total length was 498 $\mathrm{mm}, 395 \mathrm{~mm}$ and $485 \mathrm{~mm}$, and mean weight $788 \mathrm{~g}, 958 \mathrm{~g}$ and $1059 \mathrm{~g}$ for pike, perch and pikeperch, respectively. Vemco V9P-2L (47 mm long, $6.3 \mathrm{~g}$ in the air, $90 \mathrm{~s}$ mean burst interval, mean battery life 385 days, pressure sensor that gave the fish depth) and V8-4L ( $20.5 \mathrm{~mm}$ long, $2 \mathrm{~g}$ in the air, $90 \mathrm{~s}$ mean burst interval, mean battery life 163 days, no pressure sensor) acoustic transmitters were used. Twelve pike, 22 perch and the 37 pikeperch had a tag with a pressure sensor. The transmitter weight in the air did not exceed $2 \%$ of the fish body weight in accordance with literature recommendations (Winter, 1996; Snobl et al., 2015). Great attention was paid to fish welfare during fish handling and surgery, and all protocols were accepted by the veterinary authority.

\subsection{Fish tracking}

An array of 40 underwater VR2W 69kHz omnidirectional acoustic receivers (Vemco) with their associated synchronization tag (V13-1L) plus eight reference tags were anchored at the bottom (between 0.65 and $1.5 \mathrm{~m}$ above the bottom), and throughout the reservoir between January 2012 and March 2014 (Figure 1, for details see Roy et al., 2014; Westrelin et al., 2018). The synchronization tags, deployed at known locations, allowed for the correction of the receiver internal clock drift and thus indicated the exact time of each detection (Smith, 2013). The reference tags, also deployed at known locations but different from those of the receivers, were spread all over the reservoir to detect potential anomalies in the network. Vemco Positioning System was used to calculate 2D fish positions that were filtered according to Roy et al. (2014) recommendations; the mean position error was $3.3 \mathrm{~m}$ throughout the reservoir. Fish depth was assessed using pressure sensors (accuracy of $0.5 \mathrm{~m}$ and resolution of $0.075 \mathrm{~m}$ in our environmental conditions). Only the positions recorded after a minimum of 2 days after release were included in the analyses to limit potential effects of surgery (Bridger \& Booth, 2003; Vehanen \& Lahti, 2003). At the end of the study, 16 stationary individuals ( 3 pike, 3 perch, 8 pikeperch) were considered to be dead or to have lost their tag rapidly after release and 18 individuals ( 5 pike, 4 perch, 3 pikeperch) were rarely located (less than 5 days in a season). These 34 individuals were removed from the analyses. Hence, 9 pike, 22 perch and 26 pikeperch ( 8 from farm), corresponding to 5-8 pike, 12-20 perch, 14-23 pikeperch individuals depending on the season, were subsequently used in the analyses (Table 1). The time series of their positions used in this study are represented on Online Resources 2, 3 and 4 for pike, perch and pikeperch, respectively.

\subsection{Data analysis}

\subsubsection{Timescales}

Analyses were conducted according to season and daily cycle. The four seasons (Table 1) corresponded to the thermal regimes (Figure 2). As water temperature regimes were very similar over the 2-year study period (Figure 2, Online Resource 5), data from the same seasons were pooled as in Westrelin et al. (2018). The daily cycle was defined at an hourly resolution. Dawn was defined as the period including the hour preceding the sunrise hour, 
the sunrise hour itself and the following hour. Dusk was defined as the period including the hour preceding the sunset hour, the sunset hour itself and the following hour. These two periods of the day lasted three hours each. Daytime was the period following dawn and preceding dusk; night was the period following dusk and preceding dawn.

\subsubsection{Water depth}

The lake was discretized in a $10 \mathrm{~m} \times 10 \mathrm{~m}$ grid. In each grid cell, the mean water depth, deduced from bathymetry and hourly water level, was computed (5 classes: [0; 2.5[ - littoral zone, [2.5; 5[ - sublittoral zone, [5; 7.5[, [7.5; 10[ and $[10 ; 22[\mathrm{~m})$. The deepest class had a broader range to avoid very small numbers of positions. Each fish position was associated to a grid cell. For each individual, the use of a water depth was calculated as the proportion of positions observed in the corresponding class (see Westrelin et al., 2018 for methodological details). It was then averaged across individuals and by species. The selection is the process by which an animal chooses a habitat (Johnson, 1980), in our case the water depth, and the species mean selection ratios quantify it by estimating the use of a water depth regarding its availability (Manly et al., 2002). They were calculated for each combination of season and day periods, and also for each season. The mean selection ratio pools observations from all fish of the same species in the sample, but the confidence interval accounts for the variation in water depth selection across individuals (Manly et al., 2002). When a selection ratio and confidence interval are higher or lower than 1.0 for a water depth, respectively, the preference or avoidance for this water depth is significant (Manly et al., 2002; Rogers $\&$ White, 2007).

\subsubsection{Fish depth and bottom ratio}

The fish depth in the water column was used to calculate the bottom ratio, defined as the ratio of the distance of the fish to the bottom over the water depth, varying between 0 (close to the bottom) and 1 (close to the surface). Mean individual bottom ratios were calculated over seasons and periods of the day. These individual ratios were averaged by species and their standard deviations were calculated. The effects of species, season, period of the day and water depth on individual bottom ratios were tested using beta regressions (Ferrari \& Cribari-Neto, 2004). Fish identity was considered as a random effect to explicitly account for individual variability and repeated measurements on the same individual. The full model could be written as follows:

$$
\operatorname{logit}\left(\overline{\mathrm{BR}_{\text {ind }}}\right)=\alpha+\text { SPECIES * WATER DEPTH * SEASON * DAY PERIOD }+\mathrm{s}(\text { ind })+\varepsilon
$$

where $\overline{\mathrm{BR}_{\text {ind }}}$ is the expected mean individual bottom ratio in $] 0,1[, \alpha$ is the overall intercept, day period is the period of the day, s(ind) is a smoothing function modelling the individual effects (Wood, 2008) having the advantage of getting a significance test of these effects and an evaluation of the explained variance of the model, and $\varepsilon$ is the error term following a normal distribution with zero mean. The most parsimonious simple model was selected by running a forward stepwise-based procedure (Venables \& Ripley, 2002). Following the recommendations of Richards (2008), all models having an AIC value within a range of 6 from the lowest AIC value were initially selected and, among them, the more complex models that did not have an AIC value lower than all the simpler models within which they were nested were removed. The model fitting was assessed with regards to the homogeneity and normality of the residuals (Zuur et al., 2009) and to the percentage of explained variance (Hastie \& Tibshirani, 1990). Significant interactions involving species were further analyzed by Tukey 
comparisons of pairwise estimated marginal means of the different factor levels of predictors (Lenth, 2016). The thermocline depth was calculated from vertical temperature profiles with R 3.0.1 (R Core Team, 2013) and rLakeAnalyzer package (Winslow et al., 2018). Selection ratios were generated by using adehabitatHS package (Calenge, 2006). The selection is the process by which an animal chooses a habitat (Johnson, 1980) and selection ratios quantify it by estimating the use of a habitat regarding its availability (Manly et al., 2002). Beta regressions were performed in the mgcv package (Wood, 2006) and pairwise comparisons of estimated marginal means in the emmeans package (Lenth, 2016).

Importantly, as there were no significant differences in habitat use (selection and bottom ratios) between farmed and wild pikeperch (Online Resources 6 - 9), individuals from both origins were pooled in the analyses.

\section{Results}

No significant diel pattern was observed in the selection ratio of water depth between species, seasons, and day periods (Online Resource 10), except in one case. Specifically, perch in summer preferred the littoral and sublittoral zones during dawn, dusk and night but shifted to the sublittoral and [5;7.5[ $\mathrm{m}$ water depths during daytime (Figure 3). The bottom ratio was significantly impacted by the combination of species, season and water depth but the period of the day was not involved in any significant interaction with species (Table 2). This means that the season and water depth impacted the vertical distribution of species whereas the period of the day did not (Online Resource 11). In the following, only seasonal scale is considered.

Regarding littoral - pelagic seasonal partitioning, during all seasons, pike was the species that used the littoral zone the most. This corresponded to $65.5 \%$ of the time in spring and $58.4 \%$ in summer when this zone was preferred (Figures $4 \mathrm{a}$ and $4 \mathrm{~b}$ ). In autumn and in winter, it lowered to $31.2 \%$ and $32.1 \%$, respectively (Figures $4 \mathrm{c}$ and $4 \mathrm{~d}$ ). The sublittoral zone was the second most used zone by pike all year long (range $17.9 \%-31.2 \%$ ), preferred in summer and autumn (Figures $4 \mathrm{~b}$ and $4 \mathrm{c}$ ). Its intense use of the littoral zone in spring and summer was associated with an avoidance of zones deeper than $5 \mathrm{~m}$. These deeper zones became more frequented by this species in autumn and winter. Perch was the species that used the sublittoral zone the most, range $40.0 \%$ - 42.4 $\%$ over all seasons, and also preferred it except in winter (Figures 4a to $4 \mathrm{~d}$ ). In spring and summer, perch also preferred the littoral zone which was its second most used zone (Figures $4 \mathrm{a}$ and $4 \mathrm{~b}$ ). In summer, perch also used the [5; 7.5[ $\mathrm{m}$ zone $(20.9 \%)$, zone that progressively became its second most used in autumn (Figure 4c), and evenly frequented the $[7.5 ; 10[\mathrm{~m}$ zone in winter (Figures $4 \mathrm{~d}$ ). Pikeperch did not show any strong consistent pattern across the seasons. In spring, it preferred the [5; 7.5[ $\mathrm{m}$ zone which was its most used (41.8\%) and also used [2.5; 5[ and [7.5; 10[ $\mathrm{m}$ zones (20.1\% and $17.2 \%$, respectively) (Figure 4a). In summer, its littoral use raised up to $29.1 \%$ while it used all other zones relatively homogeneously without any preference (Figure $4 \mathrm{~b}$ ). In autumn, it left the littoral (Figure 4c) and, in winter, used the deepest parts ( $40.5 \%)$ followed by the $[7.5 ; 10[$ $(29.9 \%)$ and $[5 ; 7.5[\mathrm{~m}(16.8 \%)$ ones (Figure $4 \mathrm{~d})$.

Regarding vertical seasonal partitioning, in spring, perch and pikeperch were very close to the bottom down to $10 \mathrm{~m}$ depths (Figure 5a). On the other hand, pike was very close to the bottom in the littoral zone but in the third 
quarter above perch and pikeperch in the sublittoral zone (Figure 5a). When it visited zones deeper than $5 \mathrm{~m}$, pike was much above the thermocline albeit with a very high variability (Figures 5a and 6a), again less deep than perch and pikeperch. Generally all species were closer to the surface in summer compared to spring; the between-individual variability appeared quite high though (Figures $5 \mathrm{~b}$ and $6 \mathrm{~b}$ ). Pike was found around the third deepest quarter of the water column when in its preferred littoral and sublittoral zones, above perch and pikeperch (Figure 5b). In autumn, while migrating towards deeper waters, species were getting much closer to the bottom (Figures $5 \mathrm{c}$ and $6 \mathrm{c}$ ), this being pronounced in the deepest zone in winter (Figures $5 \mathrm{~d}$ and $6 \mathrm{~d}$ ). Statistical background of these analyses is provided in Online Resource 12.

Littoral - pelagic and vertical seasonal partitionings of species are synthesized in Figure 6. The general pattern of the species distribution along the littoral - pelagic axis was the following: pike, perch and pikeperch. Pike was closer to the surface than both other species. Pikeperch was often found deeper than the other two species. This general pattern was modulated by the season, species becoming more evenly distributed from littoral to pelagic, but closer to the bottom when the lake water was mixed in autumn and winter. All species appeared more concentrated in the 0-7.5 $\mathrm{m}$ zone in spring and summer, and closer to the surface in summer, following the thermocline and avoiding the deoxygenated hypolimnion.

\section{Discussion}

The present study demonstrated that habitat partitioning occurred along both the littoral - pelagic axis and the depth axis when the three species coexisted. The main driver was seasonal and contrary to our expectation, no diel vertical migration was observed. The only significant diel pattern was the more intensive use of the pelagic zone by perch during daytime in summer.

\subsection{Seasonal movement patterns}

As expected, fish movement patterns were influenced by the season, in all likelihood, to avoid unfavorable physical conditions and to satisfy different physiological and biological requirements. We could observe that more than half of the fish, including some of the smallest ones, were mature. By considering the size of the remaining ones, we could reasonably suppose most of them as also being mature. Spring corresponds to the reproduction period of pike, perch and pikeperch (Kottelat \& Freyhof, 2007), when perch and pikeperch also move closer to the littoral to find spawning habitats (Craig, 2000). In summer, the deoxygenated and colder deep hypolimnetic waters could explain the concentration of the three species closer to the surface to reach satisfying oxygenation conditions and/or to remain the closest to their optimum temperature range (Kubecka \& Wittingerova, 1998; С̆ech \& Kubečka, 2002; Nordahl et al., 2020), following the rising of the thermocline which was very closely linked to the reservoir's hydrological management.

\subsubsection{Pike}

Pike was mainly in the littoral zone with rare incursions into the pelagic zone. Its littoral position and migrations between the littoral and central parts of the lake confirmed results of some previous studies (Chapman \& Mackay, 1984a; Chapman \& Mackay, 1984b; Cook \& Bergersen, 1988). The deepest movements of pike were observed in autumn and winter, when temperature was lower and when dissolved oxygen concentration in the 
deeper zones was not limiting. Pierce et al. (2013) also observed that depth selection by pike was constrained by low dissolved oxygen concentration in some seasons. In the present study, the limited number of pike should make us cautious about findings even if these individuals were tracked over long periods.

\subsubsection{Pikeperch}

Pikeperch used different parts of the reservoir according to the season and spent a lot of time in shallow areas in summer, which is similar to what was found in Jepsen et al. (1999), Vehanen \& Lahti (2003) and Huuskonen et al. (2019). With the exception of summer when the lake was well stratified and the deepest areas less favorable in terms of oxygen, pikeperch was generally located in the deepest decile of the water column, probably seeking darkness (Craig, 1987) or prey (Huuskonen et al., 2019). This was in complete agreement with what Gorman et al. (2019) found on the walleye (Sander vitreus), a Northern American fish close relative of the European pikeperch (Craig, 2000).

\subsubsection{Perch}

Perch frequented deep waters in winter and moved inshore in spring. This was likely associated with spawning, as observed elsewhere (Eckmann \& Imbrock, 1996). Perch remained in the littoral or epilimnetic waters until the autumn and then returned to deep waters for overwintering. Our results confirmed previous results showing that this species was more homogeneously distributed in winter than in summer (Eckmann \& Imbrock, 1996; Imbrock et al., 1996).

The seasonal variations of habitat partitioning seemed to be mainly linked to the life history traits of species. Even if water level was shown not to influence the habitat use of perch in this reservoir, the highest diversity of littoral habitats in spring and intermediate in summer, due to the water regulation scheme (Westrelin et al., 2018), could make this littoral zone even more attractive for these predatory species in these seasons. On the other hand, the lower structural complexity of littoral habitat in autumn and to a lesser extent in winter could contribute to its lower use.

\subsection{Diel movement patterns}

Whereas seasonal patterns of habitat use seem to be essentially associated with avoiding unfavorable physical conditions (Lucas \& Baras, 2001) and with finding favorable spawning sites (Eckmann \& Imbrock, 1996) or prey (Huuskonen et al., 2019), diel movements are generally interpreted as a trade-off between foraging and predator avoidance behavior (Lucas \& Baras, 2001). In general, small prey fishes in lakes escape predators by finding refuge in littoral shelters during daytime and moving offshore at night (Kubečka, 1993; Riha et al., 2015), which also seemed to be the case in the Bariousses reservoir (Goulon et al., 2018). We could have expected that these prey migrations would drive movements of piscivorous pike and perch. They are visual predators (Jepsen et al., 2001; Zamora \& Moreno-Amich, 2002) and could then be particularly attracted by the littoral zone during daytime and less at night. Pikeperch, active in twilight (Jepsen et al., 1999; Poulet et al., 2005), could have performed diel vertical migrations from the bottom to forage pelagic prey during dawn and dusk as it has been reported to forage in the pelagic zone (Craig, 1987; Huuskonen et al., 2019).

\subsubsection{Pike}

Although pike shows a diel activity pattern, being active during daytime and at rest during the night (Craig, 1996; Baktoft et al., 2012), no corresponding diel pattern emerged in habitat use in our study, as pike was in the 
littoral zone all day long. Cook \& Bergersen (1988) described pike that were positioned deeper, and in deeper waters at night, whereas Riha et al. (2015) found higher littoral densities at night.

\subsubsection{Pikeperch}

No diel vertical migration was observed for pikeperch in our study. Horký et al. (2008) found a predominant nocturnal or crepuscular activity of pikeperch which they linked to foraging and which was associated with diel migrations: resting in shallow areas at night and in deeper zones during the daytime. Jepsen et al. (1999) did not find clear diel activity rhythm, with the exception of certain periods in the late summer, when activity was predominantly nocturnal. Gorman et al. (2019) found weak evidence of diel vertical migration for walleye.

\subsubsection{Perch}

Perch movement from littoral to pelagic waters during daytime in summer was the only diel pattern highlighted by our study, which was the opposite way to the diel migration of prey. This diel pattern has already been described but seemed dependent on the trophic status of the lake (Imbrock et al., 1996; Jarvalt et al., 2005; Jacobsen et al., 2015; Nakayama et al., 2018). Imbrock et al. (1996) reported that, in summer and at night, perch rested on the littoral bottom. In our case, perch was close to the bottom all day long, in its preferred zones, except in summer when it was constrained by the physical habitat partitioning to stay close to the thermocline.

\subsection{Farmed versus wild pikeperch}

Interestingly farmed and wild pikeperch used the littoral-pelagic and vertical habitats similarly. The stress of establishing themselves in a novel environment could however lead to behavioral changes. Farmed fish are capable of adopting dispersion behavior similar to wild individuals (e.g. Solem et al., 2013; Zimmermann et al., 2013) but they need to explore more their new environment (e.g. Uglem et al., 2008; Dempster et al., 2010). This could lead to a habitat use different from wild conspecifics. Eel-tailed catfish Tandanus tandanus translocated from a reservoir to a river selected habitats that were more common in their original environment and different from the riverine individuals (Carpenter-Bundhoo et al., 2020). In a translocation experiment of wild largebodied pike and European catfish Silurus glanis, translocated individuals showed persistent larger activity spacesizes than residents but no difference in activity (Monk et al., 2020). In our case, farmed fish exploited the most favorable habitats as wild residents did which could mean that the carrying capacity of the reservoir was not reached. This could prevent stocked fish from being displaced from favorable habitats through prior-residence effects (Deverill et al., 1999). Moreover, our farmed pikeperch came from an extensive pond farm which had possibly got them used to conditions close to wild ones and could have helped them to well establish in the reservoir.

\subsection{Habitat partitioning}

The main movements of potential preys did not seem to strongly drive the habitat use of the adults of the studied piscivorous species. Our results suggest that other factors played a role, such as temperature (Nakayama et al. 2018), competition and/or intraguild predation. All tagged fishes had not reached a refuge size and the smallest could be preyed upon by the biggest piscivorous individuals present in the reservoir. It has been shown that cannibalism and intraguild predation were enhanced in low productive systems in which other prey fishes are 
lacking (Mehner et al., 1996). Typically, the smallest perch could avoid the littoral zone during daytime to escape large pike.

Although the three species have marked circadian rhythms of activity, very little evidence of diel variations of habitat partitioning existed. Pike and pikeperch stayed in their preferred habitats, littoral and deep waters, respectively. Only perch performed diel movements between the littoral and pelagic zones. The plastic nature of perch regarding the environment (Craig, 2000) probably played a role in the habitat partitioning between the three species. In a manipulative experiment that consisted of introducing pikeperch in a lake already inhabited by perch and pike, perch shifted its habitat use towards the littoral while pike was hardly affected (Schulze et al., 2006). In this case, large perch were exclusively pelagic during daytime before pikeperch introduction, and became half pelagic half littoral after (Hölker et al., 2007). Perch would then modify its habitat niche to minimize interaction with pike and pikeperch. The plasticity in habitat use of perch is associated with a generalist diet (Craig, 1978; Craig, 2000) that enables the species to coexist with more specialist species like pike and pikeperch (Schulze et al., 2012), mainly piscivorous (Kangur \& Kangur, 1998). This resource partitioning was probably enhanced by the oligotrophic nature of the Bariousses reservoir (Kobler et al., 2009; Guzzo et al., 2016) which did not offer abundant preys, forcing species to specialize in order to reduce interspecific competition (Araújo et al., 2011). Large variations of selection ratios and bottom ratios in some cases stressed that a high within-species individual variability could also be important and could correspond to the coexistence of different behavioral types using separated habitats, as already observed with pike (Kobler et al., 2009) and perch (Marklund et al., 2019). This could aim at reducing the intraspecific competition (Kobler et al., 2009).

\subsection{Conclusions}

More knowledge is needed to fully understand how predatory species coexist. Leading a similar study with different assemblages of predators (e.g. any combination from one species alone to all three together, as in our case), along with a trophic component, would allow us to validate our hypotheses regarding the underlying mechanisms of habitat partitioning. In conclusion, this study revealed the existence of seasonal habitat partitioning among these three predatory species both in the littoral - pelagic and vertical dimensions. Our results highlighted that habitat partitioning is associated with the coexistence of predatory fish species in a reservoir. This mechanism, supported by the plasticity of perch in its habitat use, could explain how pike, perch and pikeperch coexist in numerous European lakes. In the context of global change that modifies habitats and their availability, understanding coexistence mechanisms of predatory species that shape ecosystems is more than ever of crucial importance.

\section{Acknowledgements}

We would like to thank Tiphaine Peroux, Julien Dublon, Virginie Diouloufet, Mario Lepage and Charles Roqueplo for their field work, Yann Le Coarer for dGPS treatments, Maxime Logez for suggestion of some useful R packages, Nathalie Reynaud for GIS treatments and Coralie Garron and Justine Haas for English correction. We also thank numerous other people who occasionally helped in the field. We are grateful to the two anonymous reviewers for their careful reading and constructive remarks that significantly improved the finished document. 


\section{Authors' contribution}

SW: Participated to field surveys, performed data analyses, designed and wrote the paper. JC: Contributed to design the paper, made several careful readings and substantial improvements. RR: Designed the field surveys, collected the data, made exploratory analyses, carefully read and commented the paper. LT: Contributed to design the field surveys, participated to data collection, carefully read and corrected the paper. FS: Contributed to design the paper, made several careful readings and substantial improvements. CA: Contributed to design the field surveys, participated to data collection, carefully read and corrected the paper.

\section{Data Availability Statement}

Data used in this manuscript are the sole property of INRAE and EDF. They can be made available from the corresponding author upon reasonable request.

\section{References}

Araújo, M. S., D. I. Bolnick \& C. A. Layman, 2011. The ecological causes of individual specialisation. Ecology Letters 14:948-958 doi:10.1111/j.1461-0248.2011.01662.x.

Baktoft, H., K. Aarestrup, S. Berg, M. Boel, L. Jacobsen, N. Jepsen, A. Koed, J. C. Svendsen \& C. Skov, 2012. Seasonal and diel effects on the activity of northern pike studied by highresolution positional telemetry. Ecology of Freshwater Fish.

Bridger, C. J. \& R. K. Booth, 2003. The effects of biotelemetry transmitter presence and attachment procedures on fish physiology and behavior. Reviews in Fisheries Science 11:13-34 doi:10.1080/16226510390856510.

Brodersen, J., H. J. Malmquist, F. Landkildehus, T. L. Lauridsen, S. L. Amsinck, R. Bjerring, M. Sondergaard, L. S. Johansson, K. S. Christoffersen \& E. Jeppesen, 2012. Short-and long term niche segregation and individual specialization of brown trout (Salmo trutta) in species poor Faroese lakes. Environmental Biology of Fishes 93:305-318 doi:10.1007/s10641-011-9914-z.

Calenge, C., 2006. The package "adehabitat" for the R software: A tool for the analysis of space and habitat use by animals. Ecological Modelling 197:516-519 doi:10.1016/j.ecolmodel.2006.03.017.

Campbell, R. N. B., 1992. Food of an introduced population of pikeperch, Stizostedion lucioperca L., in Lake Egirdir, Turkey. Aquaculture Research 23:71-85 doi:10.1111/j.13652109.1992.tb00597.x.

Carpenter-Bundhoo, L., G. L. Butler, T. Espinoza, N. R. Bond, S. E. Bunn \& M. J. Kennard, 2020. Reservoir to river: Quantifying fine-scale fish movements after translocation. Ecology of Freshwater Fish 29:89-102 doi:https://doi.org/10.1111/eff.12490.

Casselman, J. M. \& C. A. Lewis, 1996. Habitat requirements of northern pike (Esox lucius). Canadian Journal of Fisheries and Aquatic Sciences 53:161-174 doi:10.1139/cjfas-53-S1-161.

Čech, M. \& J. Kubečka, 2002. Sinusoidal cycling swimming pattern of reservoir fishes. Journal of Fish Biology 61:456-471.

CEN, 2005. Water quality - Sampling of fish with multi-mesh gillnets EN 14757. 27.

Chapman, C. A. \& W. C. Mackay, 1984a. Direct observation of habitat utilization by northern pike. Copeia:255-258.

Chapman, C. A. \& W. C. Mackay, 1984b. Versatility in habitat use by a top aquatic predator, Esox lucius L. Journal of Fish Biology 25:109-115 doi:10.1111/j.1095-8649.1984.tb04855.x.

Chesson, P., 2000. Mechanisms of Maintenance of Species Diversity. Annual Review of Ecology and Systematics 31:343-366 doi:10.1146/annurev.ecolsys.31.1.343. 
Cook, M. F. \& E. P. Bergersen, 1988. Movements, habitat selection, and activity periods of Northern Pike in 11 mile reservoir, Colorado. Transactions of the American Fisheries Society 117:495502 doi:10.1577/1548-8659(1988)117<0495:mhsaap>2.3.co;2.

Craig, J. F., 1978. A study of the food and feeding of perch, Perca fluviatilis L., in Windermere. Freshwater Biology 8:59-68 doi:10.1111/j.1365-2427.1978.tb01426.x.

Craig, J. F., 1987. The biology of perch and related fish. Croom Helm Ltd, Beckenham (UK).

Craig, J. F., 1996. Pike: biology and exploitation. . Chapman \& Hall, London.

Craig, J. F., 2000. Percid fishes: systematics, ecology and exploitation. Blackwell Science, Oxford.

Craig, J. F., 2008. A short review of pike ecology. Hydrobiologia 601:5-16 doi:10.1007/s10750-0079262-3.

Dempster, T., P. Sanchez-Jerez, I. Uglem \& P. A. Bjørn, 2010. Species-specific patterns of aggregation of wild fish around fish farms. Estuarine, Coastal and Shelf Science 86:271-275 doi:https://doi.org/10.1016/j.ecss.2009.11.007.

Deverill, J. I., C. E. Adams \& C. W. Bean, 1999. Prior residence, aggression and territory acquisition in hatchery-reared and wild brown trout. Journal of Fish Biology 55:868-875 doi:https://doi.org/10.1111/j.1095-8649.1999.tb00723.x.

Dolinin, V., 1974. Environmental dependence of the main parameters of the respiratory function in fishes in their activity and oxygen requirement. Journal of Ichthyology 14:122-132.

EC, 2000. Directive 2000/60/EC of the European Parliament and the Council of 23rd October 2000 establishing a framework for community action in the field of water policy. Official Journal of the European Communities. vol L327:1-72.

Eckmann, R. \& F. Imbrock, 1996. Distribution and diel vertical migration of Eurasian perch (Perca fluviatilis L) during winter. Annales Zoologici Fennici 33:679-686.

Eklov, P., 1992. Group foraging versus solitary foraging efficiency in piscivorous predators - the perch, Perca fluviatilis, and pike, Esox lucius, patterns. Animal Behaviour 44:313-326 doi:10.1016/0003-3472(92)90037-a.

Eklöv, P., 1997. Effects of habitat complexity and prey abundance on the spatial and temporal distributions of perch (Perca fluviatilis) and pike (Esox lucius). Canadian Journal of Fisheries and Aquatic Sciences 54:1520-1531 doi:doi:10.1139/f97-059.

Ferrari, S. \& F. Cribari-Neto, 2004. Beta Regression for Modelling Rates and Proportions. Journal of Applied Statistics 31:799-815 doi:10.1080/0266476042000214501.

Fretwell, S. D., 1987. Food chain dynamics: the central theory of ecology? Oikos:291-301.

Gorman, A. M., R. T. Kraus, L. F. G. Gutowsky, C. S. Vandergoot, Y. Zhao, C. T. Knight, M. D. Faust, T. A. Hayden \& C. C. Krueger, 2019. Vertical Habitat Use by Adult Walleyes Conflicts with Expectations from Fishery-Independent Surveys. Transactions of the American Fisheries Society 148:592-604 doi:10.1002/tafs.10150.

Goulon, C., S. Westrelin, V. Samedy, R. Roy, J. Guillard \& C. Argillier, 2018. Complementarity of two high-resolution spatiotemporal methods (hydroacoustics and acoustic telemetry) for assessing fish distribution in a reservoir. Hydroécol Appl 20:57-84.

Guzzo, M. M., P. J. Blanchfield, A. J. Chapelsky \& P. A. Cott, 2016. Resource partitioning among top-level piscivores in a sub-Arctic lake during thermal stratification. Journal of Great Lakes Research 42:276-285 doi:https://doi.org/10.1016/j.jglr.2015.05.014.

Hairston, N. G., F. E. Smith \& L. B. Slobodkin, 1960. Community Structure, Population Control, and Competition. The American Naturalist 94:421-425 doi:10.2307/2458808.

Hastie, T. J. \& R. J. Tibshirani, 1990. Generalized additive models, volume 43 of Monographs on Statistics and Applied Probability. Chapman \& Hall, London.

Helland, I. P., C. Harrod, J. Freyhof \& T. Mehner, 2008. Co-existence of a pair of pelagic planktivorous coregonid fishes. Evolutionary Ecology Research 10:373-390.

Hölker, F., H. Dörner, T. Schulze, S. S. Haertel-Borer, S. D. Peacor \& T. Mehner, 2007. Speciesspecific responses of planktivorous fish to the introduction of a new piscivore: implications for prey fitness. Freshwater Biology 52:1793-1806 doi:10.1111/j.1365-2427.2007.01810.x.

Horký, P., O. Slavík \& L. Bartoš, 2008. A telemetry study on the diurnal distribution and activity of adult pikeperch, Sander lucioperca (L.), in a riverine environment. Hydrobiologia 614:151 doi:10.1007/s10750-008-9503-0. 
Huuskonen, H., J. Piironen, J. Syvaranta, R. Eronen, C. Biasi, P. Kiiskinen, R. Kortet \& A. Vainikka, 2019. Diet and movements of pikeperch (Sander lucioperca) in a large oligotrophic lake with an exceptionally high pikeperch yield. Ecology of Freshwater Fish doi:10.1111/eff.12495.

Imbrock, F., A. Appenzeller \& R. Eckmann, 1996. Diel and seasonal distribution of perch in Lake Constance: a hydroacoustic study and in situ observations. Journal of Fish Biology 49:1-13.

Irz, P., A. Laurent, S. Messad, O. Pronier \& C. Argillier, 2002. Influence of site characteristics on fish community patterns in French reservoirs. Ecology of Freshwater Fish 11:123-136.

Jacobsen, L., S. Berg, H. Baktoft \& C. Skov, 2015. Behavioural strategy of large perch Perca fluviatilis varies between a mesotrophic and a hypereutrophic lake. Journal of Fish Biology 86:1016-1029 doi:10.1111/jfb.12613.

Jarvalt, A., T. Krause \& A. Palm, 2005. Diel migration and spatial distribution of fish in a small stratified lake. Hydrobiologia 547:197-203 doi:10.1007/s10750-005-4160-z.

Jepsen, N., S. Beck, C. Skov \& A. Koed, 2001. Behavior of pike (Esox lucius L.) $>50 \mathrm{~cm}$ in a turbid reservoir and in a clearwater lake. Ecology of Freshwater Fish 10:26-34 doi:10.1034/j.16000633.2001.100104.x.

Jepsen, N., A. Koed \& F. Okland, 1999. The movements of pikeperch in a shallow reservoir. Journal of Fish Biology 54:1083-1093.

Johnson, D. H., 1980. The comparison of usage and availability measurements for evaluating resource preference. Ecology 61:65-71 doi:10.2307/1937156.

Jones, J. R. E., 1964. Fish and River Pollution. Butterworths.

Kangur, A. \& P. Kangur, 1998. Diet composition and size-related changes in the feeding of pikeperch, Stizostedion lucioperca (Percidae) and pike, Esox lucius (Esocidae) in the Lake Peipsi (Estonia). Italian Journal of Zoology 65:255-259.

Kobler, A., T. Klefoth, T. Mehner \& R. Arlinghaus, 2009. Coexistence of behavioural types in an aquatic top predator: a response to resource limitation? Oecologia 161:837-847 doi:10.1007/s00442-009-1415-9.

Kottelat, M. \& J. r. Freyhof, 2007. Handbook of European freshwater fishes. Publications Kottelat.

Kubečka, J., 1993. Night inshore migration and capture of adult fish by shore seining. Aquaculture Research 24:685-689.

Kubecka, J. \& M. Wittingerova, 1998. Horizontal beaming as a crucial component of acoustic fish stock assessment in freshwater reservoirs. Fisheries Research 35:99-106.

Lenth, R. V., 2016. Least-Squares Means: The R Package 1smeans. Journal of Statistical Software 69:1-33 doi:10.18637/jss.v069.i01.

Liedke, A. M. R., R. M. Bonaldo, B. Segal, C. E. L. Ferreira, L. T. Nunes, A. P. Burigo, S. Buck, L. G. R. Oliveira-Santos \& S. R. Floeter, 2017. Resource partitioning by two syntopic sister species of butterflyfish (Chaetodontidae). Journal of the Marine Biological Association of the United Kingdom 98:1767-1773 doi:10.1017/S0025315417001321.

Lucas, M. C. \& E. Baras, 2001. Migration of Freshwater Fishes. Blackwell Science Ltd, Oxford.

Magnuson, J. J., L. B. Crowder \& P. A. Medvick, 1979. Temperature as an ecological resource. American Zoologist 19:331-343.

Manly, B. F. J., L. L. McDonald, D. L. Thomas, T. L. MacDonald \& W. P. Erikson, 2002. Resource selection by animals : statistical design and analysis for field studies, Second edition edn. Kluwer academic publishers, Boston, Massachussets, USA.

Marklund, M. H. K., R. Svanback, L. Faulks, M. F. Breed, K. Scharnweber, Y. H. Zha \& P. Eklov, 2019. Asymmetrical habitat coupling of an aquatic predator-The importance of individual specialization. Ecology and Evolution 9:3405-3415 doi:10.1002/ece3.4973.

Mehner, T., H. Schultz, D. Bauer, R. Herbst, H. Voigt \& J. Benndorf, 1996. Intraguild predation and cannibalism in age-0 perch (Perca fluviatilis) and age-0 zander (Stizostedion lucioperca): Interactions with zooplankton succession, prey fish availability and temperature. Annales Zoologici Fennici 33:353-361.

Monk, C. T., B. Chéret, P. Czapla, D. Hühn, T. Klefoth, E. Eschbach, R. Hagemann \& R. Arlinghaus, 2020. Behavioural and fitness effects of translocation to a novel environment: Whole-lake experiments in two aquatic top predators. Journal of Animal Ecology 89:2325-2344 doi:https://doi.org/10.1111/1365-2656.13298. 
Nakayama, S., P. Doering-Arjes, S. Linzmaier, J. Briege, T. Klefoth, T. Pieterek \& R. Arlinghaus, 2018. Fine-scale movement ecology of a freshwater top predator, Eurasian perch (Perca fluviatilis), in response to the abiotic environment over the course of a year. Ecology of Freshwater Fish 27:798-812 doi:10.1111/eff.12393.

Nordahl, O., P. Koch-Schmidt, P. Tibblin, A. Forsman \& P. Larsson, 2020. Vertical movements of coastal pike (Esox lucius) — On the role of sun basking. Ecology of Freshwater Fish 29:18-30 doi:https://doi.org/10.1111/eff.12484.

Pekcan-Hekim, Z., J. Horppila, L. Nurminen \& J. Niemistö, 2005. Diel changes in habitat preference and diet of perch (Perca fluviatilis), roach (Rutilus rutilus) and white bream (Abramis björkna). Archiv für Hydrobiologie Special Issues in Advances in Limnology 59:173-187.

Pierce, R. B., A. J. Carlson, B. M. Carlson, D. Hudson \& D. F. Staples, 2013. Depths and Thermal Habitat Used by Large versus Small Northern Pike in Three Minnesota Lakes. Transactions of the American Fisheries Society 142:1629-1639 doi:10.1080/00028487.2013.822422.

Pothoven, S. A., 2018. Seasonal feeding ecology of co-existing native and invasive benthic fish along a nearshore to offshore gradient in Lake Michigan. Environmental Biology of Fishes 101:1161-1174 doi:10.1007/s10641-018-0766-7.

Poulet, N., C. Arzel, S. Messad, S. Lek \& C. Argillier, 2005. Diel activity of adult pikeperch Sander lucioperca (L.) in a drainage canal in the Mediterranean basin during spring. Hydrobiologia 543:79-90 doi:10.1007/s10750-004-6823-6.

R Core Team, 2013. R: A language and environment for statistical computing. R Foundation for Statistical Computing, Vienna, Austria. 2013. ISBN 3-900051-07-0.

Raat, A. J., 1988. Synopsis of biological data on the northern pike: Esox lucius Linnaeus, 1758. Food \& Agriculture Org.

Raby, G. D., T. B. Johnson, S. T. Kessel, T. J. Stewart \& A. T. Fisk, 2019. Pop-off data storage tags reveal niche partitioning between native and non-native predators in a novel ecosystem. Journal of Applied Ecology doi:10.1111/1365-2664.13522.

Richards, S. A., 2008. Dealing with overdispersed count data in applied ecology. Journal of Applied Ecology 45:218-227.

Riha, M., D. Ricard, M. Vasek, M. Prchalova, T. Mrkvicka, T. Juza, M. Cech, V. Drastik, M. Muska, M. Kratochvil, J. Peterka, M. Tuser, J. Sed'a, P. Blabolil, M. Blaha, J. Wanzenbock \& J. Kubecka, 2015. Patterns in diel habitat use of fish covering the littoral and pelagic zones in a reservoir. Hydrobiologia 747:111-131 doi:10.1007/s10750-014-2124-x.

Rogers, K. B. \& G. C. White, 2007. Analysis of Movement and Habitat Use from Telemetry Data. In Guy, C. S. B., M.L. (ed) Analysis and interpretation of freshwater fisheries data. American Fisheries Society, Bethesda, Maryland, USA, 961p.

Ross, S. T., 1986. Resource partitioning in fish assemblages - A review of field studies. Copeia:352388 doi:10.2307/1444996.

Roy, R., J. Beguin, C. Argillier, L. Tissot, F. Smith, S. Smedbol \& E. De-Oliveira, 2014. Testing the VEMCO Positioning System: spatial distribution of the probability of location and the positioning error in a reservoir. Animal Biotelemetry 2.

Sala, E. \& E. Ballesteros, 1997. Partitioning of space and food resources by three fish of the genus Diplodus (Sparidae) in a Mediterranean rocky infralittoral ecosystem. Marine Ecology Progress Series 152:273-283 doi:10.3354/meps152273.

Schmitz, O. J., 2007. Predator diversity and trophic interactions. Ecology 88:2415-2426 doi:10.1890/06-0937.1.

Schoener, T., 1986. Resource partitioning. In Kikkawa, J. \& D. Anderson (eds) Community ecology: pattern and process. Blackwell Scientific Publications, Oxford, U.K., 96-126.

Schulze, T., U. Baade, H. Dorner, R. Eckmann, S. S. Haertel-Borer, F. Holker \& T. Mehner, 2006. Response of the residential piscivorous fish community to introduction of a new predator type in a mesotrophic lake. Canadian Journal of Fisheries and Aquatic Sciences 63:2202-2212 doi:10.1139/f06-099.

Schulze, T., H. Dörner, U. Baade \& F. Hölker, 2012. Dietary niche partitioning in a piscivorous fish guild in response to stocking of an additional competitor - The role of diet specialisation. Limnologica 42:56-64 doi:https://doi.org/10.1016/j.limno.2011.08.001. 
Sinclair, A. R. E., S. Mduma \& J. S. Brashares, 2003. Patterns of predation in a diverse predator-prey system. Nature 425:288 doi:10.1038/nature01934.

Smith, F., 2013. Understanding HPE in the VPS Telemetry System. VEMCO Tutorials.

Snobl, Z. R., R. P. Koenigs, R. M. Bruch \& F. P. Binkowski, 2015. Do Tags Exceeding 2\% of Total Body Weight Impair Lake Sturgeon Movement? North American Journal of Fisheries Management 35:880-884 doi:10.1080/02755947.2015.1069425.

Solem, O., R. D. Hedger, H. A. Urke, T. Kristensen, F. Okland, E. M. Ulvan \& I. Uglem, 2013. Movements and dispersal of farmed Atlantic salmon following a simulated-escape event. Environmental Biology of Fishes 96:927-939 doi:10.1007/s10641-012-0088-0.

Sommer, U., 1999. Ecology - Competition and coexistence. Nature 402:366-367 doi:10.1038/46453.

Souchon, Y. \& L. Tissot, 2012. Synthesis of thermal tolerances of the common freshwater fish species in large Western Europe rivers. Knowledge and Management of Aquatic Ecosystems:03.

Thiem, J. D., M. K. Taylor, S. H. McConnachie, T. R. Binder \& S. J. Cooke, 2011. Trends in the reporting of tagging procedures for fish telemetry studies that have used surgical implantation of transmitters: a call for more complete reporting. Reviews in Fish Biology and Fisheries 21:117-126.

Thorpe, J. E., 1977. Morphology, physiology, behavior, and ecology of Perca fluviatilis L. and P. flavescens Mitchill. Journal of the Fisheries Board of Canada 34:1504-1514.

Uglem, I., P. A. Bjørn, T. Dale, S. Kerwath, F. Økland, R. Nilsen, K. Aas, I. Fleming \& R. S. McKinley, 2008. Movements and spatiotemporal distribution of escaped farmed and local wild Atlantic cod (Gadus morhua L.). Aquaculture Research 39:158-170 doi:https://doi.org/10.1111/j.1365-2109.2007.01872.x.

Vehanen, T. \& M. Lahti, 2003. Movements and habitat use by pikeperch (Stizostedion lucioperca (L.)) in a hydropeaking reservoir. Ecology of Freshwater Fish 12:203-215 doi:10.1034/j.16000633.2003.00026.x.

Venables, W. N. \& B. D. Ripley, 2002. Random and mixed effects Modern Applied Statistics with S. Springer, 271-300.

Verberk, W., P. J. J. van den Munckhof \& B. J. A. Pollux, 2012. Niche segregation in two closely related species of stickleback along a physiological axis: explaining multidecadal changes in fish distribution from iron-induced respiratory impairment. Aquatic Ecology 46:241-248 doi:10.1007/s10452-012-9395-y.

Westrelin, S., R. Roy, L. Tissot-Rey, L. Bergès \& C. Argillier, 2018. Habitat use and preference of adult perch (Perca fluviatilis L.) in a deep reservoir: variations with seasons, water levels and individuals. Hydrobiologia 809:121-139 doi:10.1007/s10750-017-3454-2.

Winslow, L., J. Read, R. Woolway, J. Brentrup, T. Leach, J. Zwart, S. Albers \& D. Collinge, 2018. Package 'rLakeAnalyzer'.

Winter, J., 1996. Advances in underwater biotelemetry. Fisheries techniques, 2nd edition American Fisheries Society, Bethesda, Maryland:555-590.

Wood, S., 2006. Generalized additive models: an introduction with R. CRC press.

Wood, S. N., 2008. Fast stable direct fitting and smoothness selection for generalized additive models. Journal of the Royal Statistical Society: Series B (Statistical Methodology) 70:495-518.

Zamora, L. \& R. Moreno-Amich, 2002. Quantifying the activity and movement of perch in a temperate lake by integrating acoustic telemetry and a geographic information system. Hydrobiologia 483:209-218 doi:10.1023/a:1021396016424.

Zimmermann, E. W., C. F. Purchase, I. A. Fleming \& J. Brattey, 2013. Dispersal of wild and escapee farmed Atlantic cod (Gadus morhua) in Newfoundland. Canadian Journal of Fisheries and Aquatic Sciences 70:747-755 doi:10.1139/cjfas-2012-0428.

Zuur, A. F., E. N. Ieno, N. J. Walker, A. A. Saveliev \& G. M. Smith, 2009. Mixed effects models and extensions in ecology with R; Gail M, Krickeberg K, Samet JM, Tsiatis A, Wong W, editors. New York, NY: Spring Science and Business Media. 


\section{Tables}

Table 1 Number of individuals (n) tracked by season for each species with the total number of positions (Npos). The total length (TL, mm, mean and range) and weight (W, g, mean and range) are given at the time of tagging.

\begin{tabular}{|c|c|c|c|c|c|}
\hline & & Spring & Summer & Autumn & Winter \\
\hline \multirow[t]{4}{*}{ Pike } & $\mathrm{n}$ & 5 & 8 & 5 & 5 \\
\hline & Npos & 22,244 & 32,996 & 44,729 & 54,359 \\
\hline & $\mathrm{TL}$ & $\begin{array}{l}553 \\
425-629\end{array}$ & $\begin{array}{l}535 \\
425-629\end{array}$ & $\begin{array}{l}515 \\
425-596\end{array}$ & $\begin{array}{l}553 \\
425-629\end{array}$ \\
\hline & $\mathrm{W}$ & $\begin{array}{l}1072 \\
398-1513\end{array}$ & $\begin{array}{l}978 \\
398-1513\end{array}$ & $\begin{array}{l}861 \\
398-1221\end{array}$ & $\begin{array}{l}1072 \\
398-1513\end{array}$ \\
\hline \multirow[t]{4}{*}{ Perch } & $\mathrm{n}$ & 13 & 20 & 16 & 12 \\
\hline & Npos & 170,032 & 214,035 & 194,037 & 263,292 \\
\hline & TL & $\begin{array}{l}412 \\
320-486\end{array}$ & $\begin{array}{l}404 \\
320-486\end{array}$ & $\begin{array}{l}415 \\
320-486\end{array}$ & $\begin{array}{l}409 \\
320-486\end{array}$ \\
\hline & $\mathrm{W}$ & $\begin{array}{l}1033 \\
383-1800\end{array}$ & $\begin{array}{l}964 \\
383-1800\end{array}$ & $\begin{array}{l}1071 \\
383-1800\end{array}$ & $\begin{array}{l}990 \\
383-1800\end{array}$ \\
\hline \multirow[t]{4}{*}{ Pikeperch } & $\mathrm{n}$ & 14 & 23 & 17 & 18 \\
\hline & Npos & 70,650 & 185,519 & 282,974 & 269,500 \\
\hline & $\mathrm{TL}$ & $\begin{array}{l}464 \\
360-596\end{array}$ & $\begin{array}{l}507 \\
360-695\end{array}$ & $\begin{array}{l}502 \\
360-695\end{array}$ & $\begin{array}{l}477 \\
360-695\end{array}$ \\
\hline & W & $\begin{array}{l}931 \\
354-1914\end{array}$ & $\begin{array}{l}1223 \\
354-3000\end{array}$ & $\begin{array}{l}1221 \\
354-3000\end{array}$ & $\begin{array}{l}1038 \\
354-3000\end{array}$ \\
\hline
\end{tabular}


Table 2 Numeric results from the Beta regression that tested the fixed effects of season, water depth, species, period of the day and their interactions, on individual bottom ratios. Fish identity was used as a random effect.

\begin{tabular}{llll}
\hline \multirow{2}{*}{ ALL SPECIES } & \multicolumn{2}{l}{ Bottom ratio } & p-value \\
\cline { 2 - 4 } Season & d.f. & Chi-sq & $<0.001$ \\
Water depth & 3 & 87.953 & $<0.001$ \\
Species & 4 & 84.081 & 0.091 \\
Day period & 2 & 4.794 & 0.081 \\
Season: Water depth & 3 & 6.732 & $<0.001$ \\
Season: Species & 12 & 42.866 & $<0.001$ \\
Water depth: Species & 6 & 32.393 & $<0.001$ \\
Water depth: Day period & 8 & 52.708 & $<0.001$ \\
Season: Water depth: Species & 24 & 48.498 & $<0.001$ \\
Individual & 51 & 133.768 & $<0.001$ \\
& 51220 & \\
\cline { 2 - 4 } & Fixed effects & Fixed and random & \\
\hline
\end{tabular}




\section{Figures}

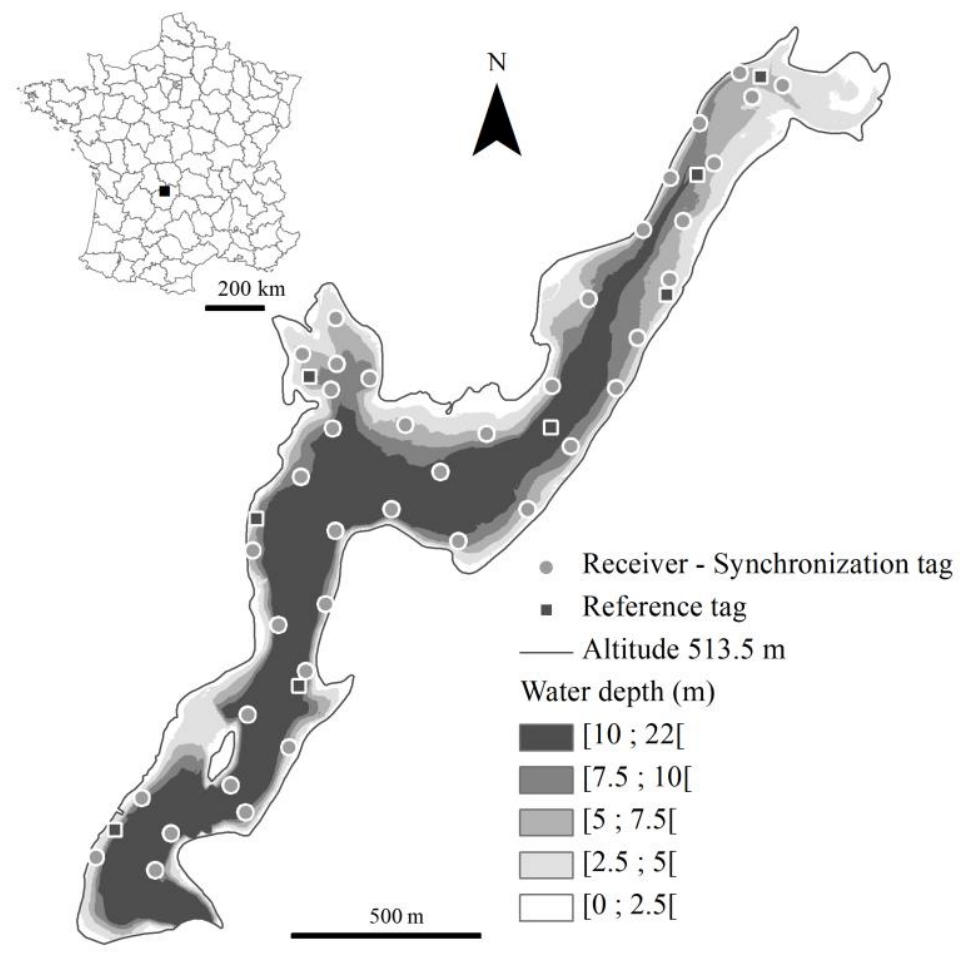

Fig. 1 Location of the study site (black square over France map with department boundaries) and bathymetric map of the Bariousses reservoir at the high water level with the location of the receivers and synchronizing tags (adapted from Westrelin et al., 2018). 


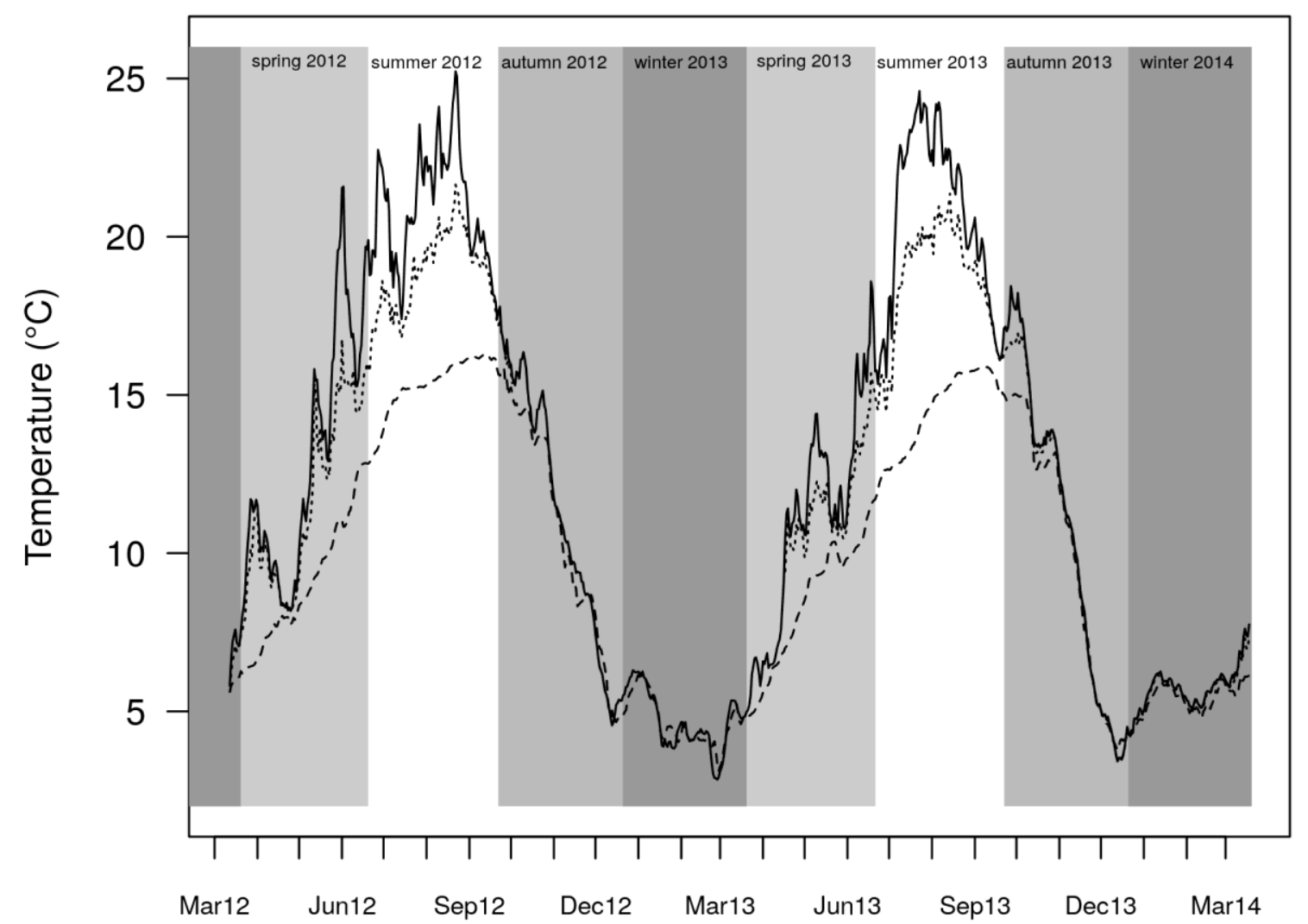

Fig. 2 Mean daily temperature $\left({ }^{\circ} \mathrm{C}\right.$ ) measured at three different depths (solid, dotted and dashed lines for $0.5,3.5$ and $18.5 \mathrm{~m}$, respectively) at the deepest point of the lake. The shading of periods in deep dark grey, dark grey, light grey and white represents winter (mixed water), autumn (mixing occurring), spring (stratified water) and summer (stratified water), respectively. 


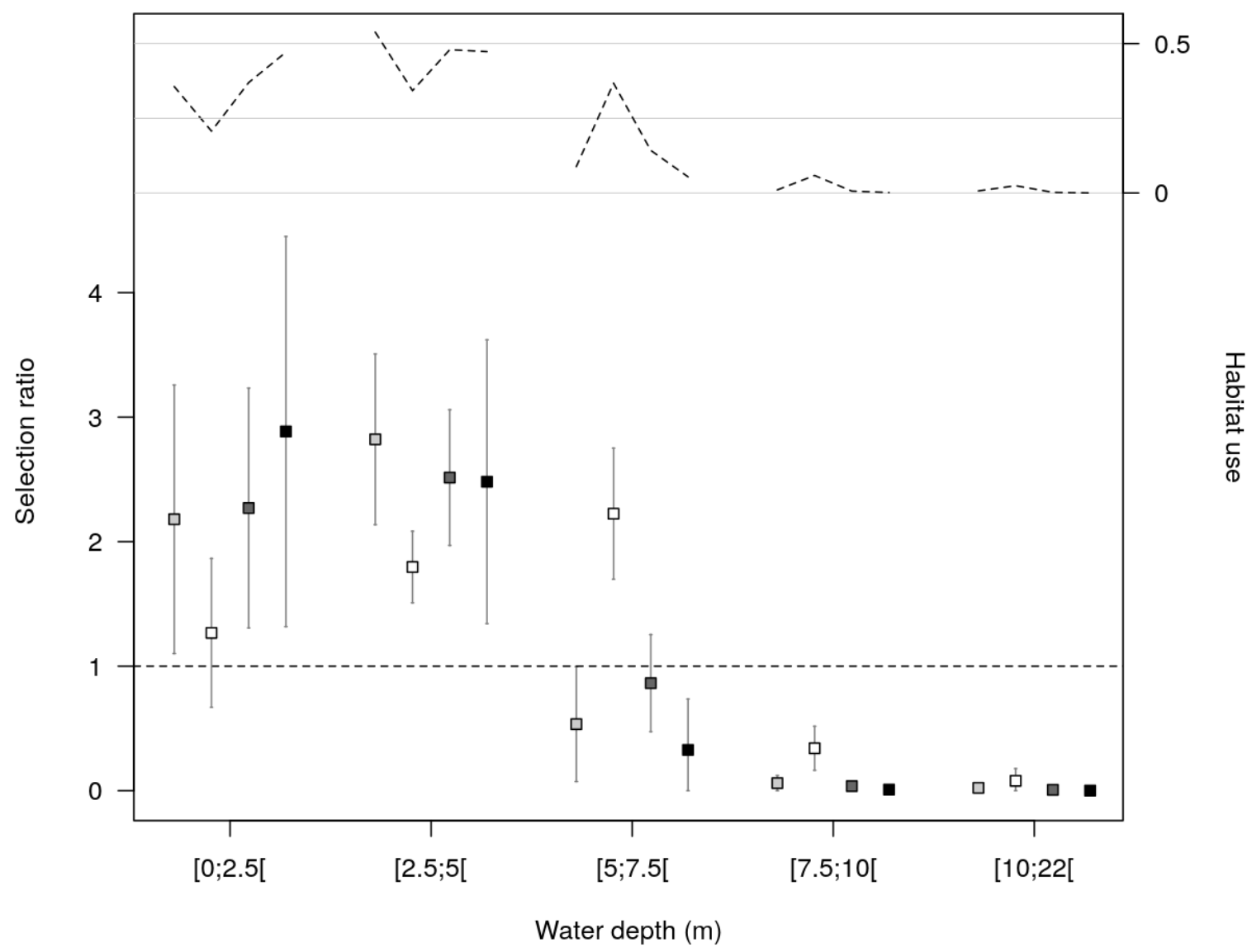

Fig. 3 Selection ratio of water depth (Mean $\pm 95 \%$ Bonferroni confidence interval) for perch $(n=20)$ in summer for each period of the day (light grey, white, dark grey and black squares for dawn, daytime, dusk and night, respectively) on the left axis. A selection ratio of 1 indicates "no preference" and is represented by a horizontal dashed line. Habitat use (used proportion of each water depth) is represented on the right axis with a dashed line. 

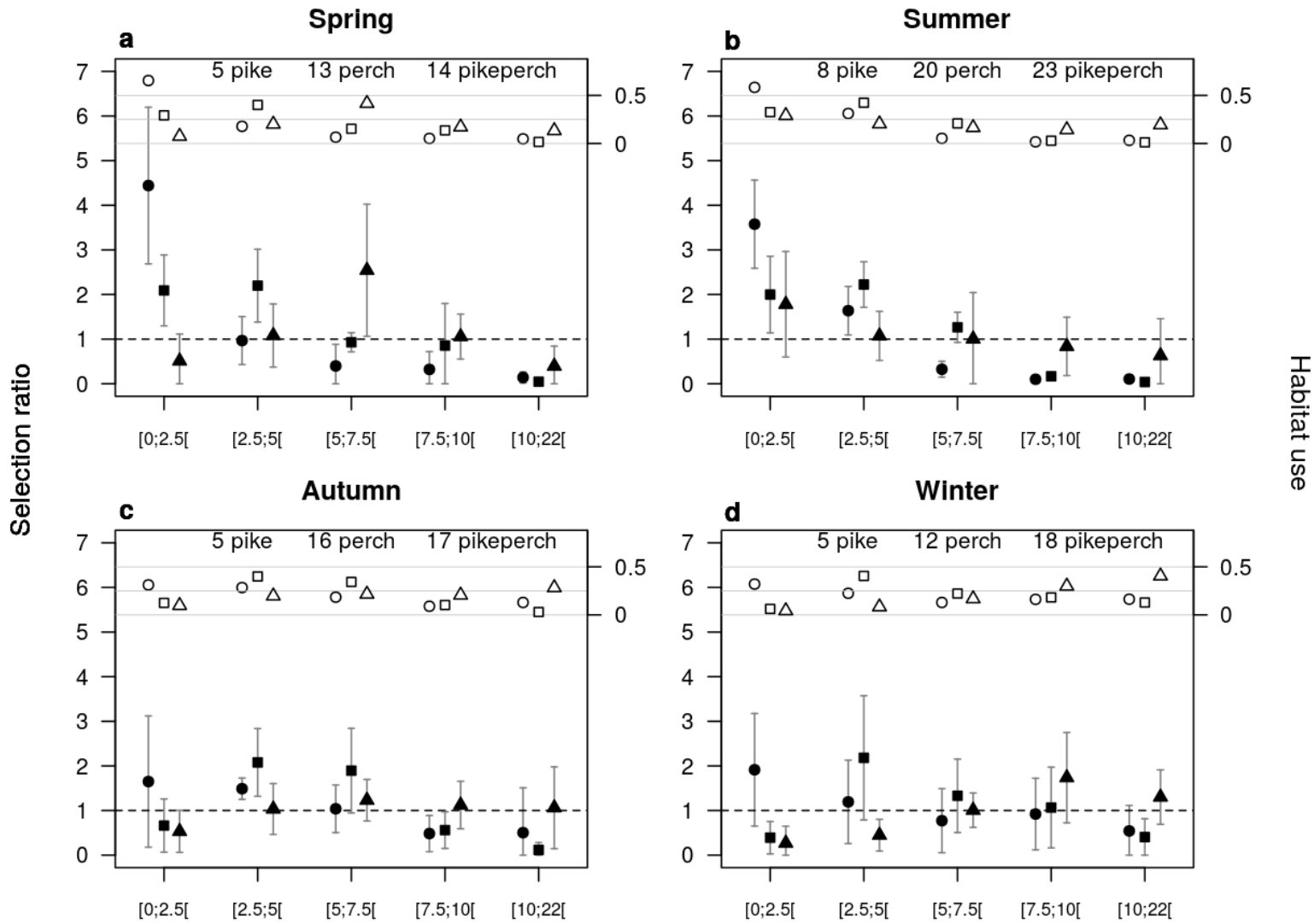

Water depth (m)

Fig. 4 Selection ratio of water depth (Mean $\pm 95 \%$ Bonferroni confidence interval) in each season (spring, summer, autumn and winter in panels a, b, c and d, respectively) and for each species (black dots, black squares and black triangles for pike, perch and pikeperch, respectively) on the left axis. A selection ratio of 1 indicates "no preference" and is represented by a horizontal dashed line. Habitat use (used proportion of each water depth) is represented on the right axis (circles, white squares and white triangles for pike, perch and pikeperch, respectively). In each season, the number of pike, perch and pikeperch taken into account is provided. 


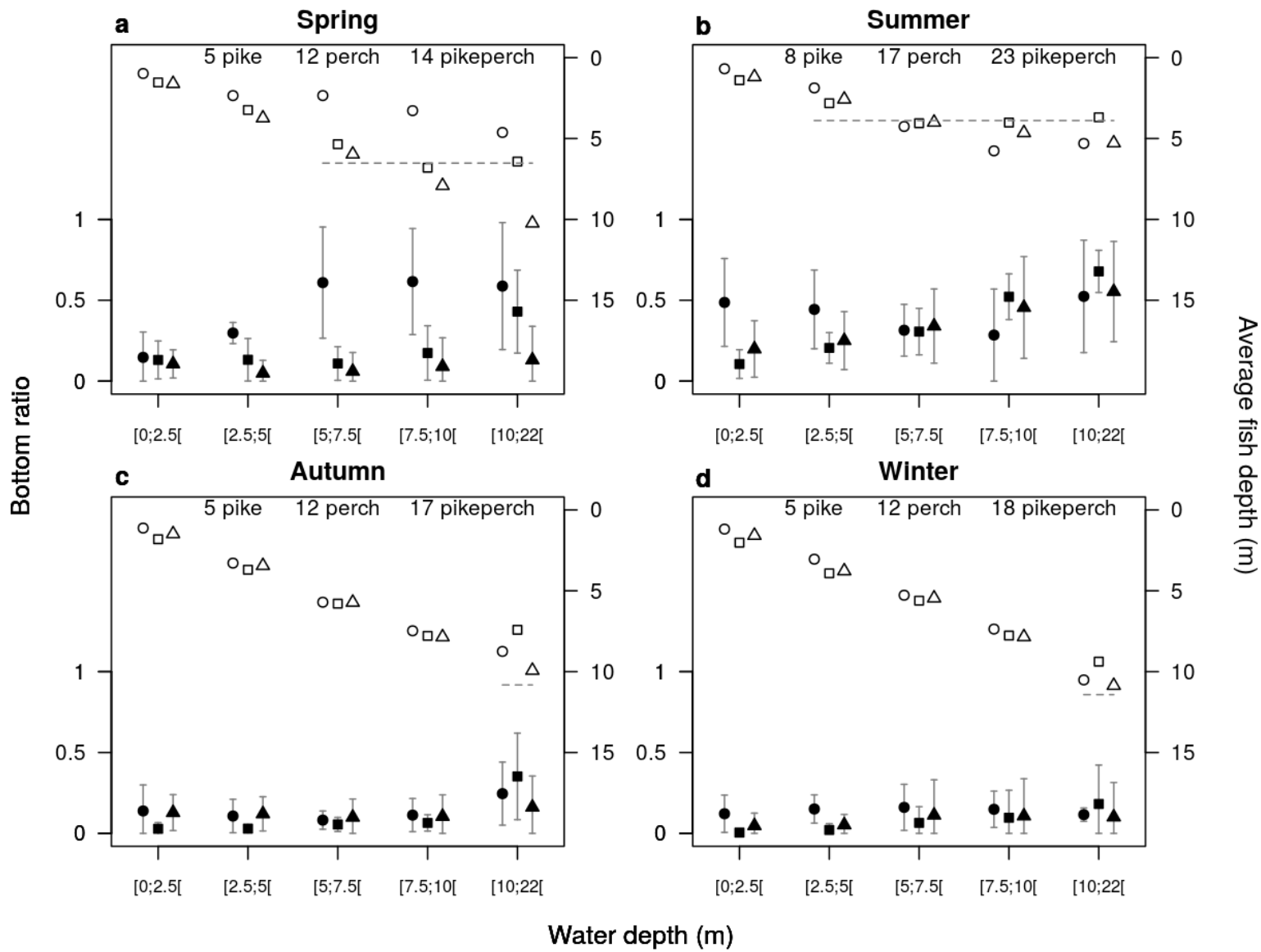

Fig. 5 Bottom ratio (Mean \pm SD) in each season (a) spring, b) summer, c) autumn and d) winter) for each species (black dots, black squares and black triangles for pike, perch and pikeperch, respectively) on the left axis. The average depth of species (circles, white squares and white triangles for pike, perch and pikeperch, respectively) and of the thermocline (grey dashed line) are represented on the right axis. In each season, the number of pike, perch and pikeperch taken into account is provided. 


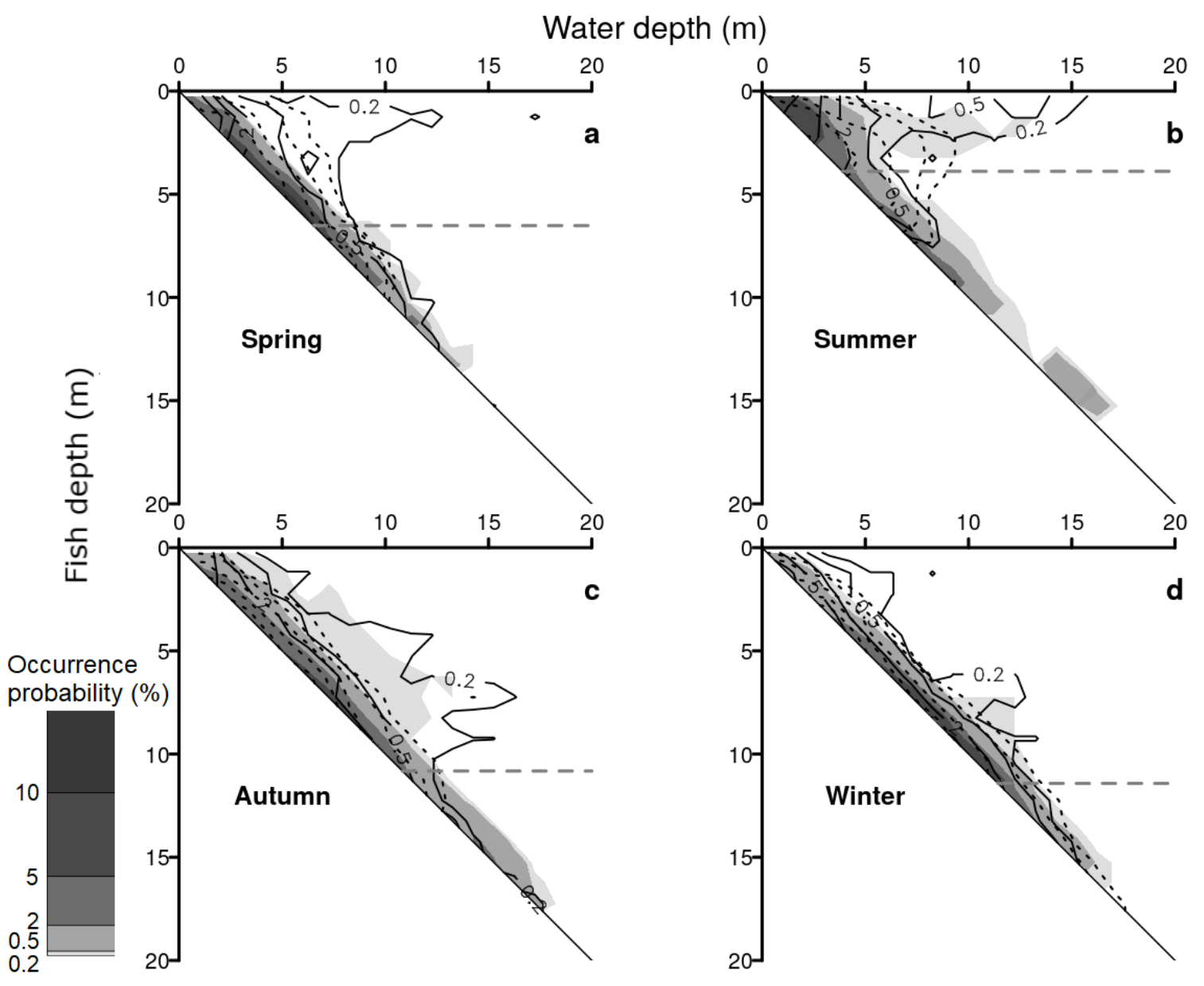

Fig. 6 Occurrence probability (\%) of each species (black solid, black dashed and grey-filled contours for pike, perch and pikeperch, respectively) along the littoral-pelagic and depth axes in each season (a) spring, b) summer, c) autumn and d) winter). The occurrence probability at one point of the space defined by the water depth and the fish depth is the proportion of positions (\%) at this point. It has been calculated over $1 \mathrm{~m}$-sided cells. The thermocline mean depth is represented by the horizontal grey dashed line. 
Supplementary materials for: Habitat partitioning among three predatory fish in a temperate reservoir Samuel Westrelin ${ }^{(1)}$, Julien Cucherousset ${ }^{(2)}$, Romain Roy ${ }^{(3)}$ Laurence Tissot $^{(3)}$, Frédéric Santoul $^{(4)}$, Christine Argillier $^{(1)}$

(5) INRAE, Aix Marseille Univ, Pôle R\&D ECLA, HYNES, RECOVER, 13182, AIX-EN-PROVENCE, FRANCE

INRAE

Aix Marseille Univ

Pôle R\&D ECLA (OFB - INRAE - USMB)

HYNES (INRAE - EDF R\&D)

UR RECOVER

3275 Route de Cézanne - CS 40061

F-13182 Aix-en-Provence Cedex 5

FRANCE

(6) UMR5174 EDB

CNRS, Université Paul Sabatier, ENFA

118 route de Narbonne

31062 Toulouse

FRANCE

(7) EDF R\&D

LNHE Department

HYNES (INRAE-EDF R\&D)

6 Quai Watier

CHATOU Cedex 78401

France

(8) Laboratoire écologie fonctionnelle et environnement

Université de Toulouse, CNRS

Toulouse

FRANCE

Online Resource 1: Seasonal oxygen and temperature vertical profiles in 2011.

Online resources 2, 3 and 4: Time series of the positions of pike, perch and pikeperch respectively

Online Resource 5: Comparison of seasonal mean daily temperature profiles between the different years (from spring 2012 to winter 2014).

Online resources 6 and 7: Mean individual seasonal selection ratio of water depth class for pikeperch according to their origin (farmed or wild) and the results of the generalized additive mixed-effects model testing the origin effect

Online resources 8 and 9: Mean individual seasonal bottom ratio for pikeperch according to their origin (farmed or wild) and the results of the beta regression testing the origin effect

Online resource 10: Mean selection ratio of water depth class for pike, perch and pikeperch according to season and period of the day 
Online resource 11: Mean bottom ratio for pike, perch and pikeperch according to season and period of the day

Online resource 12: Estimated marginal means of bottom ratio for the different species, season and depth combinations 

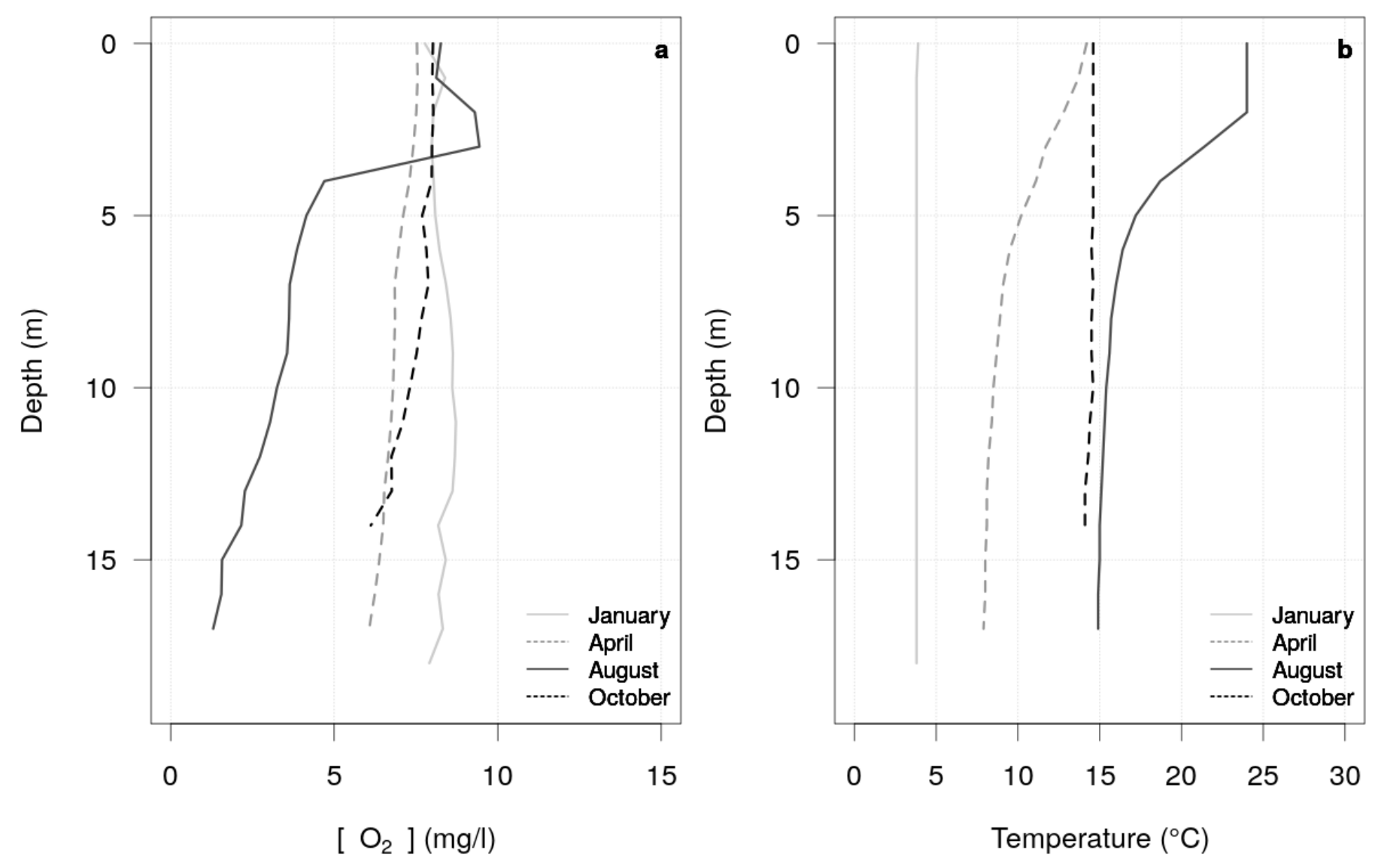

Online Resource 1 Seasonal oxygen and temperature vertical profiles in 2011 (panels a and b, respectively). The profiles in solid grey, dashed grey, solid black and dashed black lines were measured on $20^{\text {th }}$ January, $21^{\text {st }}$ April, $23^{\text {rd }}$ August and $19^{\text {th }}$ October 2011, respectively, close to the dam in the southern part of the Bariousses reservoir. 


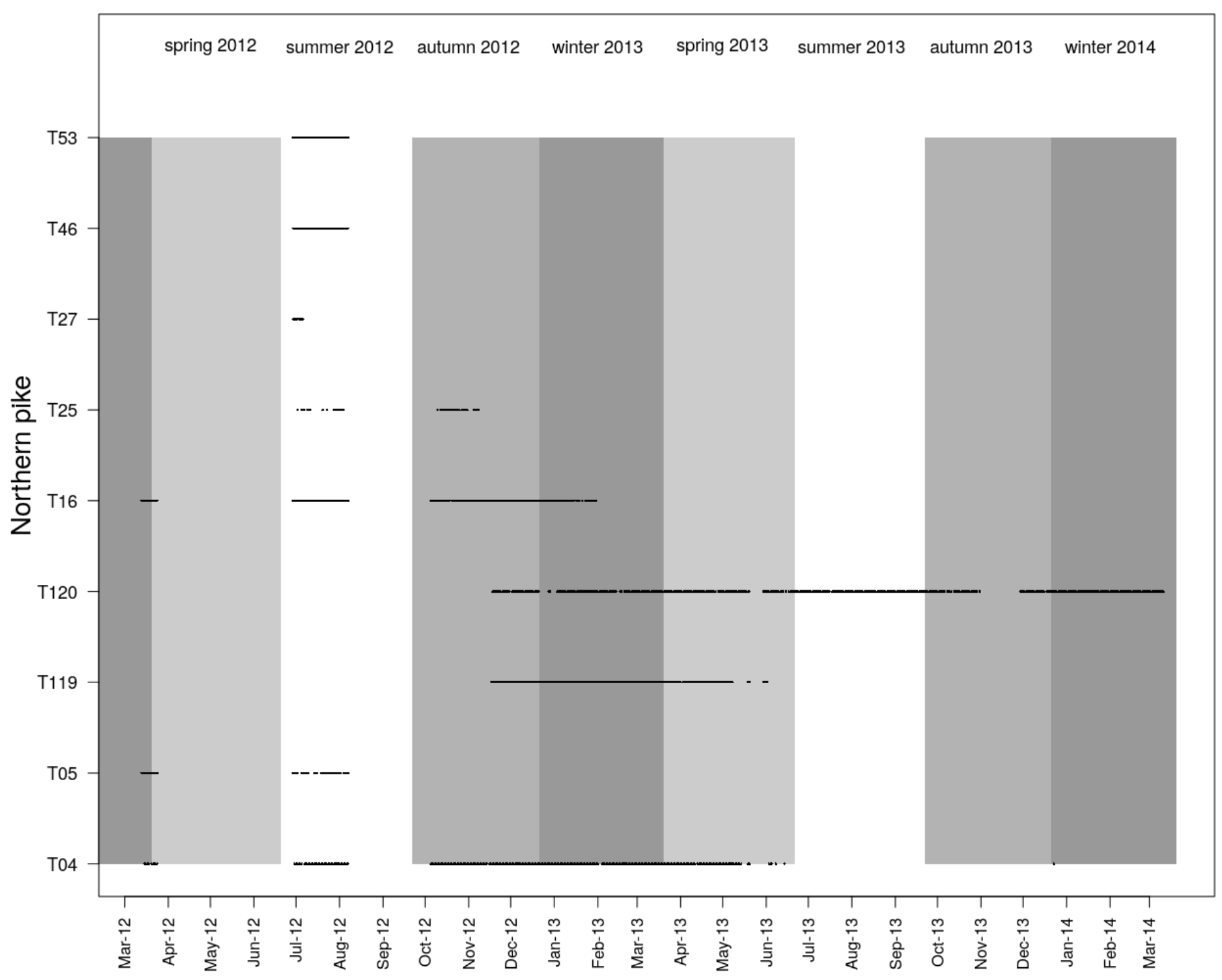

Online Resource 2 Time series of the positions of pike, Esox lucius (black dots). The shading of periods in dark grey, grey, light grey and no shading are representative of winter, autumn, spring and summer, respectively. 


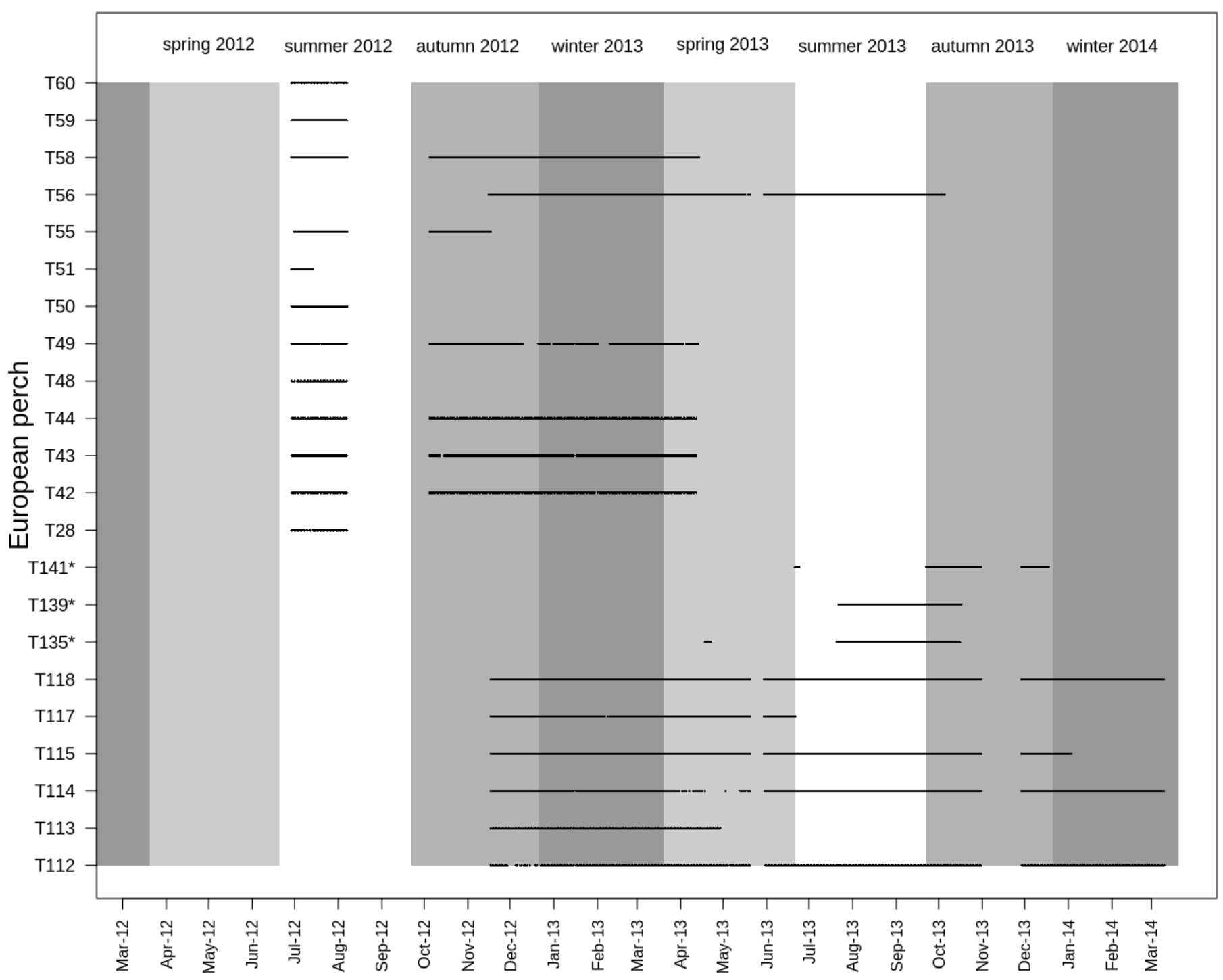

Online Resource 3 Time series of the positions of perch, Perca fluviatilis (black dots). * indicates tags without pressure sensor. The shading of periods in dark grey, grey, light grey and no shading are representative of winter, autumn, spring and summer, respectively. 


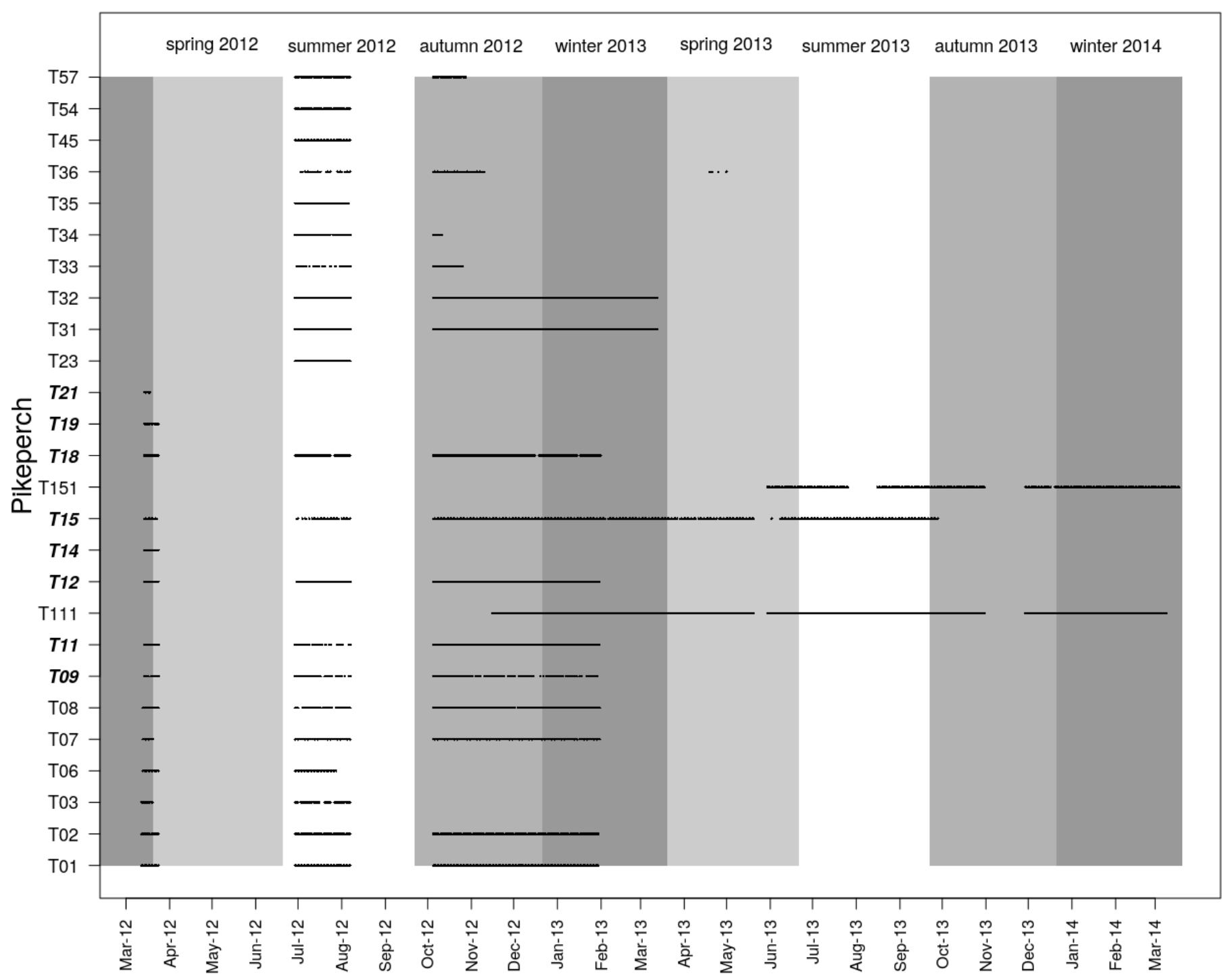

Online Resource 4 Time series of the positions of pikeperch, Sander lucioperca (black dots). Italic bold ID indicates farmed pikeperch. The shading of periods in dark grey, grey, light grey and no shading are representative of winter, autumn, spring and summer, respectively. 
Online Resource 5 Comparison of seasonal mean daily temperature profiles between the different years (from spring 2012 to winter 2014). The distributions of mean daily temperatures at three depths $(0.5,3.5$ and $18.5 \mathrm{~m}$ corresponding to Figure 2) were compared between the same seasons of the different years with a KruskalWallis test. When temperatures are different, both means are given; when they are not different, the global mean is given. P-values are given in italics. In spring, temperatures between 2012 and 2013 were not different at 3.5 and $18.5 \mathrm{~m}$ but at $0.5 \mathrm{~m}$, the mean temperature was warmer in 2012 than in $2013\left(13.0^{\circ} \mathrm{C}\right.$ and $11.1{ }^{\circ} \mathrm{C}$, respectively). In summer, temperatures between 2012 and 2013 were not different at 0.5 and $3.5 \mathrm{~m}$; at $18.5 \mathrm{~m}$, the mean temperature was warmer in 2012 than in 2013 by $0.8^{\circ} \mathrm{C}$. In autumn, temperatures between 2012 and 2013 were not different at 0.5 and $18.5 \mathrm{~m}$. The comparison was not made at $3.5 \mathrm{~m}$ but, except in early fall, temperature was very homogeneous all along the vertical profile in autumn (see Figure 2). The winter was colder in 2013 compared to 2014 by about $1{ }^{\circ} \mathrm{C}$ in average. Yet temperatures during both winters were much cooler than in any other season and characteristic of this season. In general, temperature differences between years ranged between a $1{ }^{\circ} \mathrm{C}$ interval, the biggest difference appearing in spring when the surface layer was warmer in 2012 compared to 2013 by about $2{ }^{\circ} \mathrm{C}$. Aside these values, each season clearly kept its main features whatever the year with rapidly increasing temperatures in spring, water stratification all along the summer when the temperatures were the highest, fast decreasing temperatures in autumn and cool and relatively stable temperatures in winter (see Figure 2). This led us to pool data from the same seasons over the two-year study.

\begin{tabular}{lllll}
\hline \multirow{2}{*}{0.5 m depth } & Spring & Summer & Winter \\
\cline { 2 - 5 } & $\overline{\mathrm{T}_{2012}}=13.0$ & $\overline{\mathrm{T}}=20.7$ & $\overline{\mathrm{T}}=10.9$ & $\overline{\mathrm{T}_{2013}}=4.7$ \\
& $\overline{\mathrm{T}_{2013}}=11.1$ & & $\overline{\mathrm{T}_{2014}}=5.8$ \\
& 0.009 & 0.99 & 0.29 & $<0.001$ \\
\cline { 2 - 4 } $3.5 \mathrm{~m}$ depth & $\overline{\mathrm{T}}=11.7$ & $\overline{\mathrm{T}}=18.7$ & $(1)$ & No data in 2013 \\
& 0.31 & 0.83 & & \\
\cline { 2 - 4 } & $\overline{\mathrm{T}}=8.7$ & $\overline{\mathrm{T}_{2012}}=15.3$ & $\overline{\mathrm{T}}=10.3$ & $\overline{\mathrm{T}_{2013}}=4.1$ \\
& & $\overline{\mathrm{T}_{2013}}=14.5$ & & $\overline{\mathrm{T}_{2014}}=5.1$ \\
& $<.11$ & $<0.001$ & 0.15 & $<0.001$
\end{tabular}

(1) As only the first 10 days of autumn are available in 2012 at $3.5 \mathrm{~m}$ depth, the comparison was not made with the full time series in 2013 (90 days). 

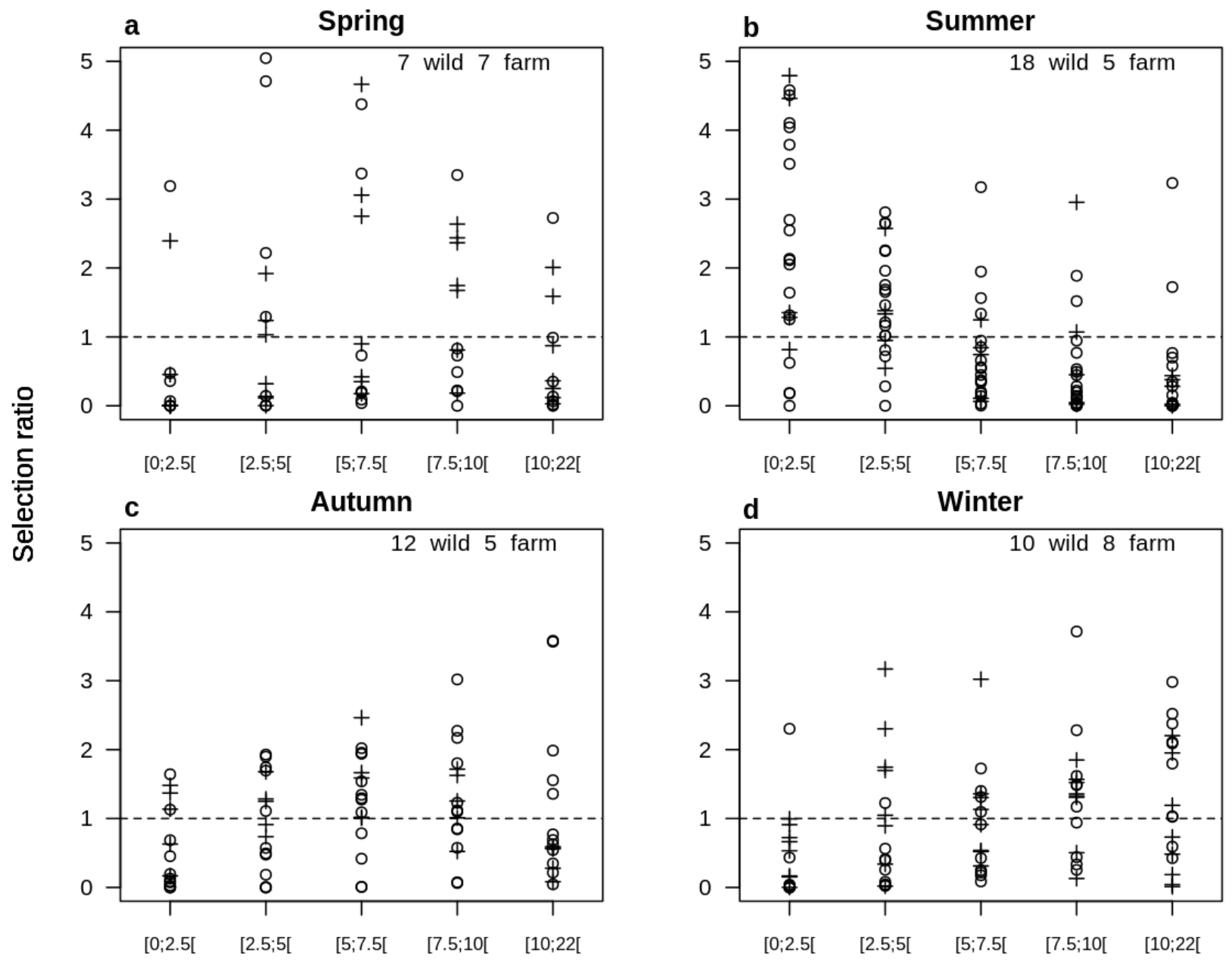

Water depth (m)

Online Resource 6 Mean individual selection ratio of water depth in each season (spring, summer, autumn and winter in panels a, b, c and d, respectively) for pikeperch (crosses for farmed individuals and white dots for wild individuals). In each season, the numbers of farmed and wild pikeperch are provided. 
Online Resource 7 Results of the following generalized additive mixed-effects model

$$
\log \left(\overline{\mathrm{SR}_{\text {ind }}}\right)=\alpha+\text { WATER DEPTH } * \text { SEASON }+ \text { WATER DEPTH } * \text { ORIGIN }+\mathrm{s}(\text { ind })+\varepsilon
$$

where $\overline{\mathrm{SR}_{\text {ind }}}$ is the expected mean individual selection ratio of pikeperch, strictly positive; $\alpha$ is the overall intercept; origin discriminates wild from farmed pikeperch, $s$ (ind) is a smoothing function modelling the individual effects (Wood, 2008) and $\varepsilon$ is the error term following a normal distribution with zero mean. To take into account the skewed distribution of individual selection ratios towards zero, a Tweedie family function with a log-link was used (Gilman et al., 2012). This model tested the fixed effects of water depth, season, pikeperch origin and some of their interactions, as well as the individual effects, on selection ratios. The percentage of explained variance quantified the data variability represented by this model. Results demonstrated that there was no effect of pikeperch origin.

\begin{tabular}{llll}
\hline Pikeperch & \multicolumn{2}{l}{ Selection ratio } & p-value \\
\cline { 2 - 4 } & d.f. & F & 0.018 \\
Water depth & 4 & 3.008 & $<0.001$ \\
Season & 3 & 14.297 & 0.238 \\
Origin & 1 & 1.396 & $<0.001$ \\
Water depth: Season & 12 & 6.327 & 0.131 \\
Water depth: Origin & 4 & 1.786 & 1 \\
Individual & 24 & 0 & \\
\cline { 2 - 4 } & All effects & & \\
Explained variance $(\%)$ & 17.1 & & \\
\hline
\end{tabular}



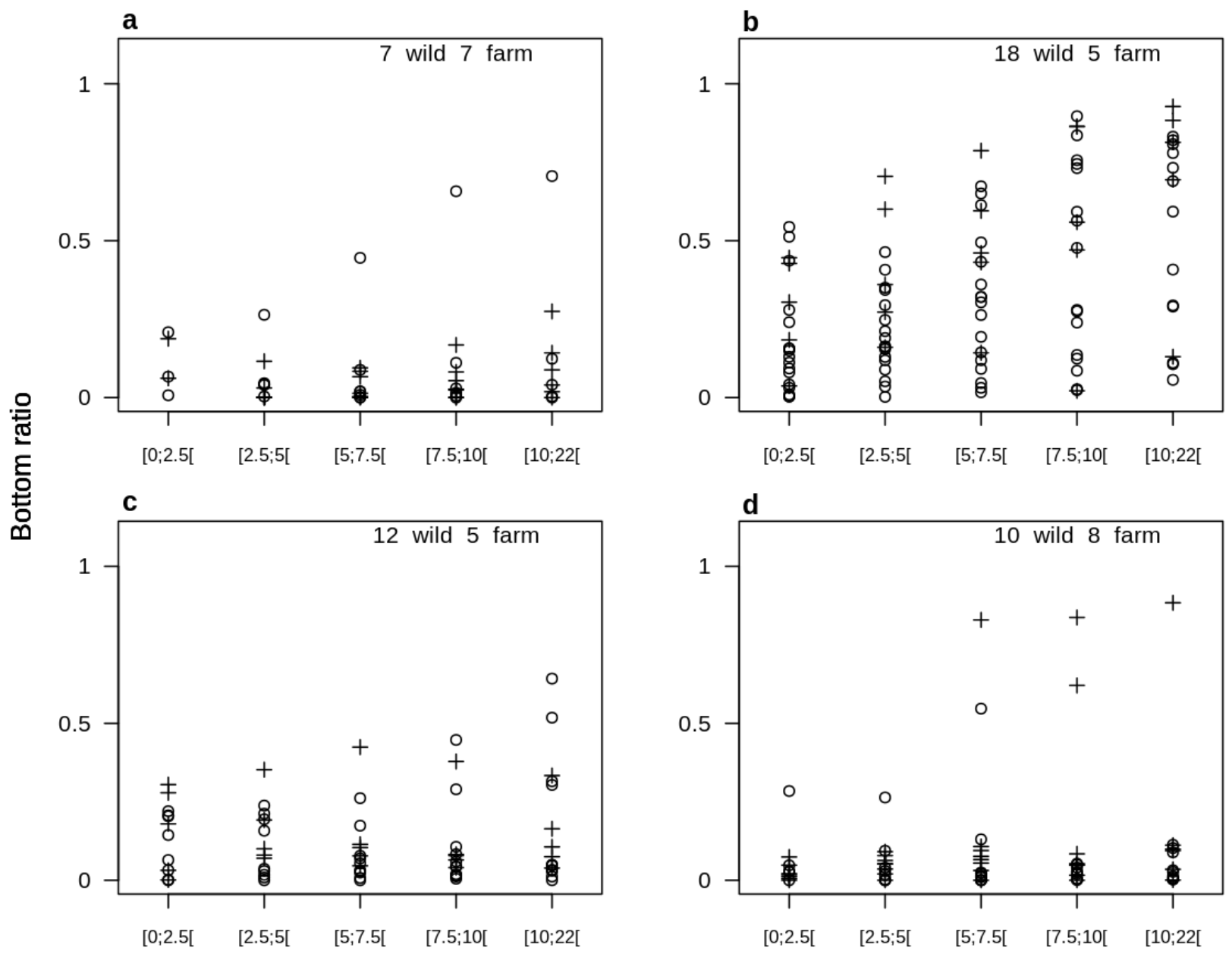

Water depth (m)

Online Resource 8 Mean individual bottom ratio in each season (spring, summer, autumn and winter in panels $\mathrm{a}, \mathrm{b}, \mathrm{c}$ and d, respectively) for pikeperch (crosses for farmed pikeperch and white dots for wild ones). In each season, the numbers of farmed and wild pikeperch are provided. 
Online Resource 9 Results of the following Beta regression

$$
\operatorname{logit}\left(\overline{\mathrm{BR}_{\text {ind }}}\right)=\alpha+\text { WATER DEPTH } * \text { SEASON }+ \text { WATER DEPTH } * \text { ORIGIN }+\mathrm{s}(\text { ind })+\varepsilon
$$

where $\overline{\mathrm{BR}_{\text {ind }}}$ is the expected mean individual bottom ratio in $] 0,1[, \alpha$ is the overall intercept, origin discriminates wild from farmed pikeperch, s(ind) is a smoothing function modelling the individual effects (Wood, 2008) and $\varepsilon$ is the error term following a normal distribution with zero mean. This model tested the fixed effects of water depth, season, pikeperch origin and some of their interactions, as well as the individual effects, on bottom ratios. The percentage of explained variance quantified the data variability represented by this model. Results demonstrated that there was no effect of pikeperch origin.

\begin{tabular}{|c|c|c|c|}
\hline \multirow[t]{2}{*}{ Pikeperch } & \multicolumn{3}{|c|}{ Bottom ratio } \\
\hline & d.f. & Chi-sq & p-value \\
\hline Water depth & 4 & 21.820 & $<0.001$ \\
\hline Season & 3 & 53.694 & $<0.001$ \\
\hline Origin & 1 & 3.527 & 0.060 \\
\hline Water depth: Season & 12 & 43.790 & $<0.001$ \\
\hline Water depth: Origin & 4 & 0.737 & 0.947 \\
\hline \multirow[t]{2}{*}{ Individual } & 24 & 177.6 & $<0.001$ \\
\hline & All e & & \\
\hline Explained variance (\%) & 50.7 & & \\
\hline
\end{tabular}




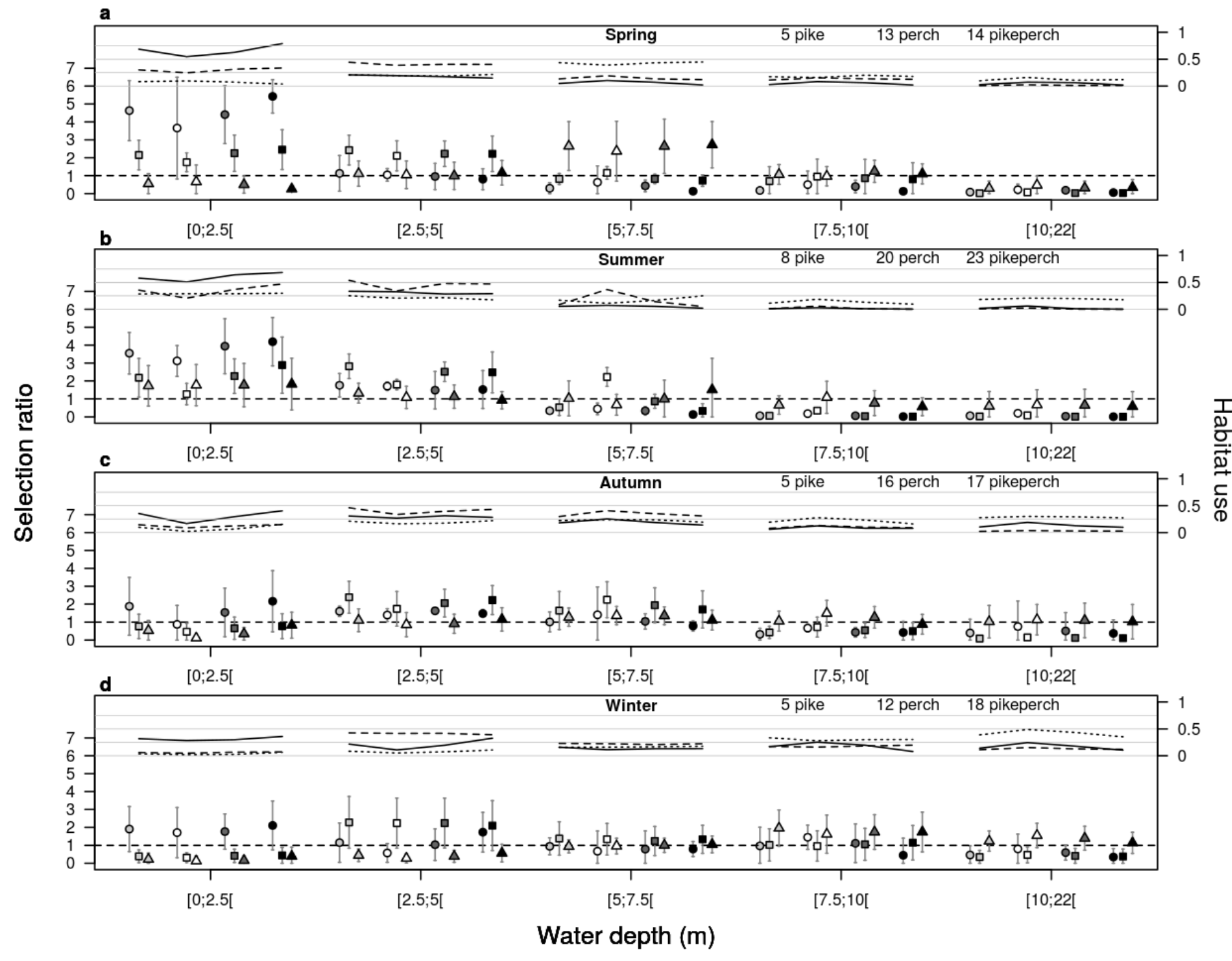

Online Resource 10 Selection ratio of water depth (mean \pm 95\% Bonferroni Confidence Interval) for each species (dots, squares and triangles for pike, perch and pikeperch, respectively) and each period of the day (dawn, daytime, dusk and night displayed in light grey, white, dark grey and black symbols, respectively) in each season (spring, summer, autumn and winter in panels a, b, c and d, respectively) on the left axis. A selection ratio of 1 indicates "no preference" and is represented by a horizontal dashed line. Habitat use (used proportion of each water depth) is represented on the right axis (solid, dashed and dotted line for pike, perch and pikeperch, respectively). In each season, the number of pike, perch and pikeperch is provided. 


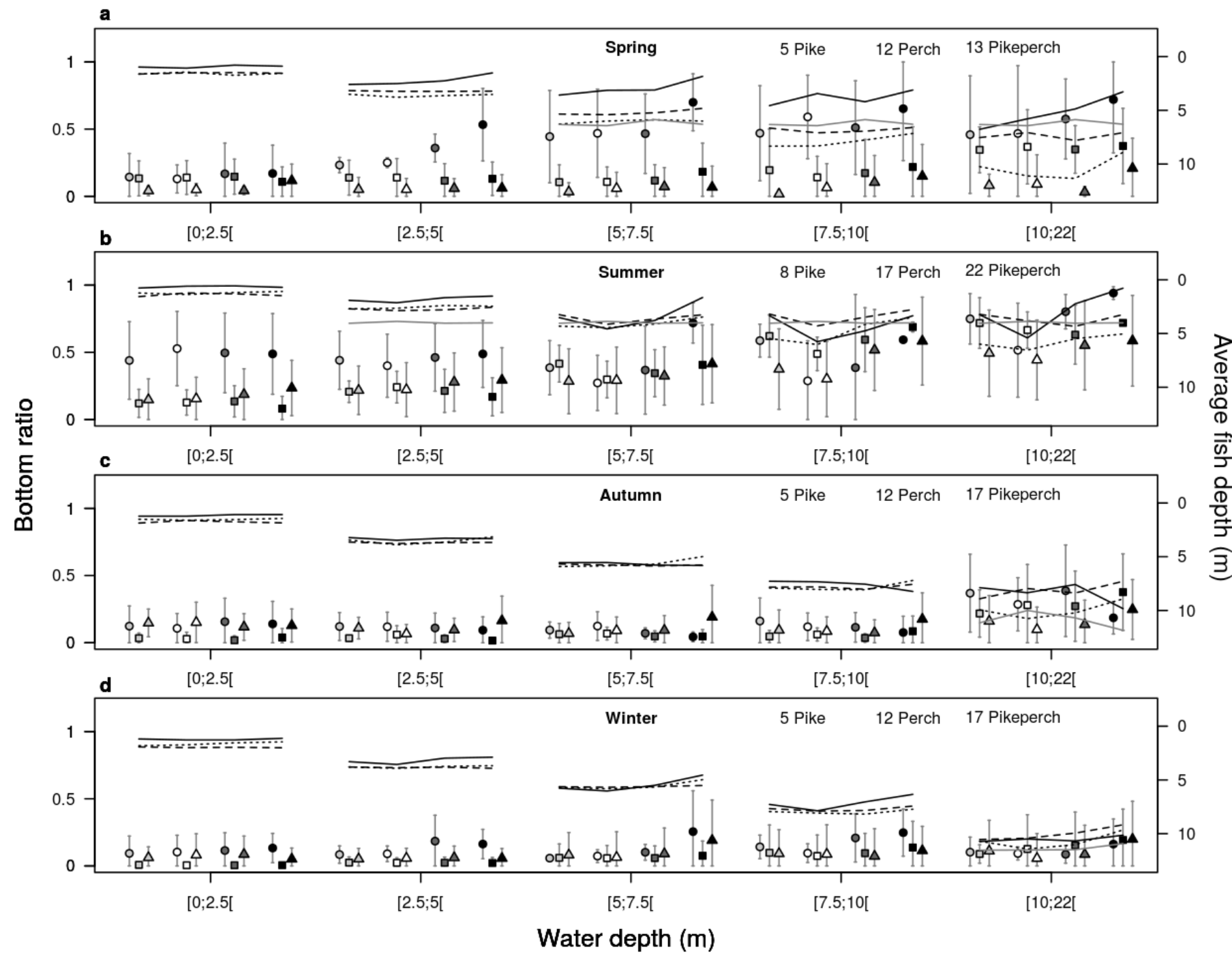

Online Resource 11 Bottom ratio (mean \pm SD) for each species (dots, squares and triangles for pike, perch and pikeperch, respectively) and each period of the day (dawn, daytime, dusk and night displayed in light grey, white, dark grey and black symbols, respectively) in each season (spring, summer, autumn and winter in panels a, b, c and d, respectively) on the left axis. The average depth of species (solid, dashed and dotted line for pike, perch and pikeperch, respectively) and of the thermocline (grey solid line) are represented on the right axis. In each season, the number of pike, perch and pikeperch is provided. 
Online Resource 12 Estimated marginal means of bottom ratio for the different species, season and water depth combinations. In each season/water depth category, estimated bottom ratios that are significantly different between species (based on Tukey comparisons of pairwise estimated marginal means at the $95 \%$ level of the beta regression) are labelled with different letters (a, b, c).

\begin{tabular}{|c|c|c|c|c|c|}
\hline & Spring & & & & \\
\hline & {$[0 ; 2.5[$} & {$[2.5 ; 5[$} & {$[5 ; 7.5[$} & {$[7.5 ; 10[$} & {$[10 ; 22[$} \\
\hline Pike & $0.09^{\mathrm{a}}$ & $0.18^{\mathrm{a}}$ & $0.37^{\mathrm{a}}$ & $0.44^{\mathrm{a}}$ & $0.60^{\mathrm{a}}$ \\
\hline Perch & $0.04^{b}$ & $0.08^{\mathrm{b}}$ & $0.11^{\mathrm{b}}$ & $0.13^{b}$ & $0.30^{\mathrm{b}}$ \\
\hline \multirow[t]{3}{*}{ Pikeperch } & $0.04^{b}$ & $0.02^{\mathrm{c}}$ & $0.04^{\mathrm{c}}$ & $0.07^{\mathrm{c}}$ & $0.07^{\mathrm{c}}$ \\
\hline & Summer & & & & \\
\hline & {$[0 ; 2.5[$} & {$[2.5 ; 5[$} & {$[5 ; 7.5[$} & {$[7.5 ; 10[$} & {$[10 ; 22[$} \\
\hline Pike & $0.37^{\mathrm{a}}$ & $0.40^{\mathrm{a}}$ & $0.40^{\mathrm{a}}$ & $0.67^{\mathrm{a}}$ & $0.60^{\mathrm{a}, \mathrm{b}}$ \\
\hline Perch & $0.11^{\mathrm{b}}$ & $0.23^{b}$ & $0.41^{\mathrm{b}}$ & $0.60^{\mathrm{a}}$ & $0.72^{a}$ \\
\hline \multirow[t]{3}{*}{ Pikeperch } & $0.09^{b}$ & $0.25^{b}$ & $0.31^{\mathrm{a}}$ & $0.37^{b}$ & $0.51^{\mathrm{b}}$ \\
\hline & Autumn & & & & \\
\hline & {$[0 ; 2.5[$} & {$[2.5 ; 5[$} & {$[5 ; 7.5[$} & {$[7.5 ; 10[$} & {$[10 ; 22[$} \\
\hline Pike & $0.05^{\mathrm{a}}$ & $0.08^{\mathrm{a}}$ & $0.09^{\mathrm{a}}$ & $0.13^{\mathrm{a}}$ & $0.22^{\mathrm{a}}$ \\
\hline Perch & $0.02^{b}$ & $0.06^{\mathrm{a}}$ & $0.10^{\mathrm{a}}$ & $0.10^{\mathrm{a}}$ & $0.31^{\mathrm{a}}$ \\
\hline \multirow[t]{3}{*}{ Pikeperch } & $0.02^{\mathrm{b}}$ & $0.07^{\mathrm{a}}$ & $0.07^{\mathrm{a}}$ & $0.10^{\mathrm{a}}$ & $0.11^{\mathrm{b}}$ \\
\hline & Winter & & & & \\
\hline & {$[0 ; 2.5[$} & {$[2.5 ; 5[$} & {$[5 ; 7.5[$} & {$[7.5 ; 10[$} & {$[10 ; 22[$} \\
\hline Pike & $0.10^{\mathrm{a}}$ & $0.09^{\mathrm{a}}$ & $0.08^{\mathrm{a}}$ & $0.14^{\mathrm{a}}$ & $0.13^{\mathrm{a}, \mathrm{b}}$ \\
\hline Perch & $0.01^{\mathrm{b}}$ & $0.03^{b}$ & $0.08^{\mathrm{a}}$ & $0.12^{\mathrm{a}}$ & $0.15^{\mathrm{a}}$ \\
\hline Pikeperch & $0.01^{\mathrm{b}}$ & $0.03^{b}$ & $0.06^{\mathrm{a}}$ & $0.07^{\mathrm{b}}$ & $0.09^{b}$ \\
\hline
\end{tabular}

\section{References}

Gilman, E., M. Chaloupka, A. Read, P. Dalzell, J. Holetschek \& C. Curtice, 2012. Hawaii longline tuna fishery temporal trends in standardized catch rates and length distributions and effects on pelagic and seamount ecosystems. Aquatic Conservation-Marine and Freshwater Ecosystems 22:446-488 doi:10.1002/aqc.2237.

Wood, S. N., 2008. Fast stable direct fitting and smoothness selection for generalized additive models. Journal of the Royal Statistical Society: Series B (Statistical Methodology) 70:495-518. 